\title{
CÂTEVA OBSERVAȚII PRIVIND UNELE MORMINTE DE COPII DESCOPERITE ÎN NECROPOLA DE LA CARANSEBeŞ-CENTRU ÎN ANUl 2017, PE BAZA ANALIZELOR ANTROPOLOGICE ŞI FIZICO-CHIMICE
}

\author{
SILVIU OȚA, ALEXANDRA COMȘA, ZIZI BALTĂ, \\ CRISTIANA TĂTARU, ADRIAN ARDET, \\ DIMITRIE NEGREI, IULIAN LEONTI
}

\section{REZUMAT:}

Cercetările arheologice din orașul medieval Caransebeș, din afara ariei fortificate, au dus la descoperirea unui monument de cult și a necropolei aferente. Aceasta a fost precedată de un alt cimitir, datat în veacurile XI-XII. În biserică au fost cercetate mai multe cripte, iar în exteriorul său au fost trasate câteva casete în care erau morminte datate în secolele XIV-XVI. Săpătura a fost reluată în anul 2017, când au fost cercetate alte 35 de complexe funerare. În partea de sud a navei bisericii, a fost descoperită o grupare de morminte de înhumație deranjate, aparținătoare unor copii. Unul dintre acestea, anume M. 33/2017, a avut ca inventar funerar o monedă datată în veacul al XVI-lea, emisă în timpul domniei lui Ferdinand I (1526-1564) și resturi dintr-o țesătură. Acestea din urmă au fost identificate în spatele craniului, la câțiva centrimetri. Din ele s-au mai păstrat urme de culoare verde, provenite din procesul de oxidare pe oasele craniului.

Lucrarea de faţă cuprinde studiile antropologic şi paleopatologic al scheletului de copil, descoperit în campania arheologică din anul 2017, în mormântul nr. 33 din Biserica Medievală din Caransebeş, jud. Caraş-Severin, datat în secolul al XVI-lea. Scheletul respectiv a aparţinut unei fetiţe în vârstă de 7 ani+24 luni. Inventarul său funerar ne sugerează provenienţa ei dintr-o familie bogată. Totuşi, după cum ne indică datele paleopatologice de pe oase, ea a decedat, foarte probabil, ca urmare a îmbolnăvirii sale de scorbut. Acesta este primul caz de scorbut documentat arheologic pe teritoriul României.

Probele constând în principal din fragmente arheologice de material textil au fost analizate prin microscopie optică și spectrometrie cu fluorescență de raze X. Examinările prin microscopie optică au relevat faptul că este posibil ca bentița copilului să fi fost lucrată dintr-un material textil de mătase albastră pe care a fost aplicată o dantelă argintie lucrată cu două tipuri de fire metalice tip bandă metalică, mai subțiri (benzi înguste) și mai groase (benzi late), strâns înfăşurate în $\mathrm{S}$ pe miez textil din mătase albă nevopsită, răsucită în $\mathrm{S}$ sau în $\mathrm{Z}$.

În urma analizelor XRF a rezultat că majoritatea firelor metalice au fost produse din alamă argintată, alama având un conținut mai mic de $20 \%$ de zinc în compoziție. În funcție de conținutul în zinc al firelor metalice se poate presupune ca bentița copilului este de secolul al XVI-lea, cunoscut fiind din literatura de specialitate că alamele cu zinc mai mare de $20 \%$ în compoziție încep să apară spre sfarșitul secolului al XVI-lea ca urmare a dezvoltării procesului de cementare a cuprului topit cu calamina, de abia spre sfârșitul secolului al XVII-lea începând să se producă alame cu conținut mai mare de $33 \%$ datorită utilizării unei noi metode de obținere a alamei prin alierea cuprului cu zincul metalic brut (speltering).

Analizele fizico-chimice întăresc datarea mormântului în veacul al XVI-lea.

\section{ABSTRACT:}

The archaeological excavations in the medieval town of Caransebeș, outside the fortified area, led to the discovery of a cult monument and of the related cemetery. This one was preceded by another cemetery, dated during 11th12th centuries. Several crypts were researched inside the church and graves dated to 14th-16th centuries were found in the sections excavated outside the church. A group of disturbed children inhumation graves was found in the southern part of the nave of the church. A coin dated to the 16th century, issued during Ferdinand I reign (15261564), and remains of a tissue were found in grave 33/2017. These remains were identified a few centimeters behind the skull. Traces of green, result of the oxidation on the skull bones, have been preserved.

The present paper refers to the anthropological and paleopathologicial studies of a child skeleton, which was discovered in Burial no. 1, from the Medieval Church in Caransebeş, Caraş-Severin County, during the archaeological campaign since 2017. The mentioned skeleton belonged to a little girl, with the age of 7years +24 months. Her funerary inventory shows us that she was the member of a rich family. Still, as emphasized by the paleopathological 
data, she had died, most probably, because she was ill with scurvy. This is the first archaeologically documented case of scurvy, on the territory of Romania.

Samples consisting mainly of archaeological fragments of textile from a child headband were analyzed by light microscopy and handheld X-ray fluorescence spectrometry. By microscopical examinations in reflected light it was observed that the child's headband was probably made of a blue silk textile material on which was sewn a silvering lace woven with two types of metal threads, thinner (narrow strips) and thicker (wide strips), tightly wrapped in $\mathrm{S}$ on a textile fiber core of undyed white silk yarn twisted in $\mathrm{S}$ or $\mathrm{Z}$.

XRF analysis results showed that metal threads were made of silvered brass. Depending on the resulting zinc in brass of less than $20 \mathrm{wt} . \%$ and that zinc content of brass is considered a chronological indicator according to scientific literature, could be assumed that the child's archaeological headband dates back to the 16th century. Brass with zinc higher than $20 \mathrm{wt}$. \% appear to be produced towards the end of the 16th century as a result of the intensive development of the brass cementation process whereby copper was melted in a crucible with calamine. Only towards the end of the 17 th century brass with a content of more than $33 \mathrm{wt}$. \% zinc starts to be obtained by a new production method by direct alloying of copper with raw zinc metal (speltering).

Scientific investigation conducted on the archaeological metal thread textile fragments and on coin has suggested that the tomb may be dated as of the 16th century.

CUVINTE CHEIE: biserică, mormânt de copil, țesătură, monedă, antropologie, analize fizico-chimice.

KEYWORDS: church, child grave, textile, coin, anthropology, physico-chemical analysis.

În cursul anului 2017, în zona centrală a municipiului Caransebeș au fost reluate săpăturile arheologice la sud de biserica medievală cercetată de către Petru Bona în anii ' 80 - $^{\prime} 90$ (Pl. 1)1. Cercetarea terenului s-a desfășurat în regim de salvare, încercându-se completarea mai vechilor informații asupra cimitirului medieval ${ }^{2}$.

Acesta este unul dintre puținele identificate și cercetate arheologic în teritoriul oraşului medieval Caransebeș. Pe baza inventarului funerar a fost atribuit secolelor XIV-XVI/XVII ${ }^{3}$. În afara acestuia, a mai fost cercetat parțial cel din veacurile XI-XII din același spații ${ }^{4}$, suprapus de cel menționat mai sus. Din aceeași vreme, anume secolele XI-XII, datează și cel de la Măhala ${ }^{5}$. Alte cimitire au fost identificate, fie cu ajutorul hărților în mica fortificație din centru orașului înconjurat cu ziduri, în partea de nord vest a aceluiași punct și cea din afara cetății, spre est $^{6}$. Cea din interiorul micii cetăți interioare a fost certificate și prin descoperiri de resturi osteologice provenite din morminte și găsite în apropiere, spre vestul ei. Este vorba de oase umane descoperite în cursul campaniei arheologice din anul 2017. În anul 2018, pe o proprietate învecinată, a fost identificată la suprafața solului și baza unei posibile clădiri de cult în spațiul acestei mici fortificații, ceea ce ar corespunde cu hărțile mai vechi ale orașului ${ }^{7}$. Asocierea de resturi osteologice umane ${ }^{8}$ cu fragmente de ziduri, vin să întărească prezența unei posibile biserici anterioare anexării Banatului de Severin Imperiului Otoman, deci anterioară anului 1658. Tot cu ajutoriul informației istorice, au mai putit fi identificate relativ în teren necropolele din jurul bisericilor Sf. Ioan, Sf. Gheorghe și o alta în apropierea actulalului muzeu, unde exista o cazarmă și o altă fortificație construită foarte probabil în stil italian'.

Mormintele descoperite în campania din anul 2017, foarte multe deranjate sunt cele rămase în urma ridicării clădirilor de aici în veacul al XVIII-lea și al XIX-lea. Acestea au fost găsite în spațiul încăperilor construcțiilor, în

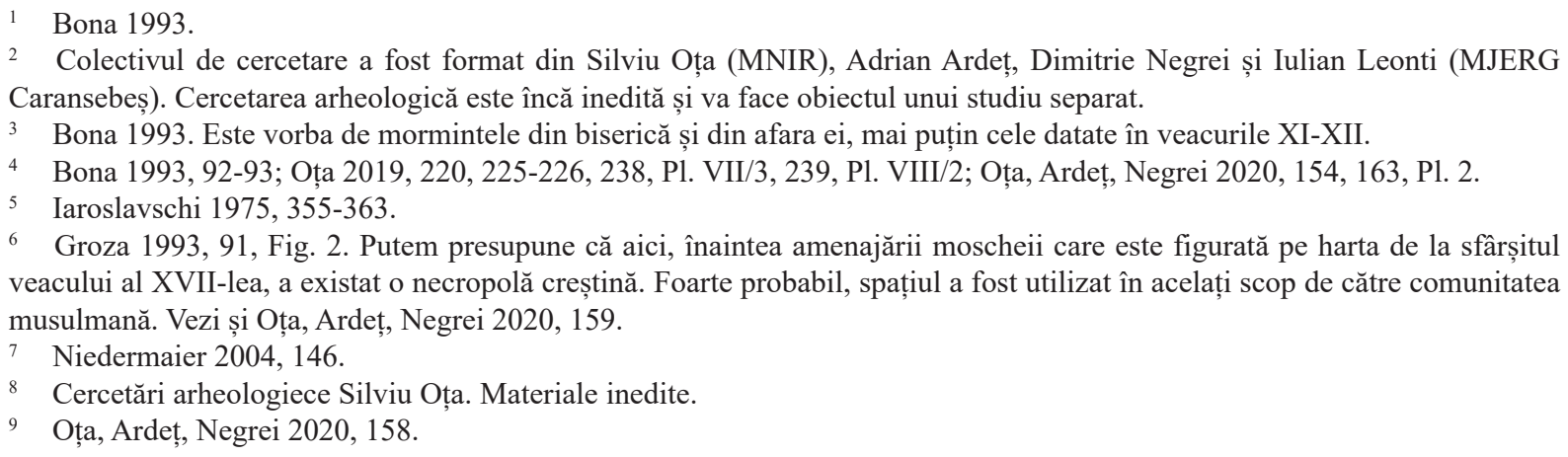


zonele nederanjate de săparea fundațiilor. Pe lângă scheletele unor adulți, cele mai multe fără inventar funerar, a fost descoperită o grupare de morminte de copii parțial deranjate, cu orientări diverse.

Un mic grup de morminte se afla la sudul navei bisericii medievale din centrul actual al orașului, spre vest (Pl. 2/3).

\section{Descrierea mormintelor}

M. 33/2017 (Pl. 2/1). Orientare: SV-NE. Mobilier funerar: sicriu. La stânga scheletului a fost găsit un cui, iar un altul mai sus de craniu, ambele provenite de la sicriu. Sex: mormânt copil, probabil o fetiță (conform inventarului), păstrat parțial, fiind deranjat în zona picioarelor, a toracelui și la mâna dreaptă. Poziție: depus pe spate, cu mâna stângă așezată de-a lungul corpului. Probabil și cea dreaptă, dacă avem în vedere osul radius sau cubitus găsit, era în aceeași poziție, dar a fost deranjată. Picioarele, probabil întinse, s-au păstrat parțial. În zona piciorului drept a fost găsit un fragment de țiglă. Inventar: 1) monedă descoperită în zona toracelui (Pl. 2/2);2) fragmente de țesătură cu fir metalic provenite de la o bonetă. Acestea au fost observabile pe craniu unde au lăsat o urmă de culoare verde, apoi după descompunere și tasarea pământului a alunecat în spatele său, de unde au fost recuperate câteva fragmente.

M. 34/2017 (Pl. 2/1). Orientare: SV-NE. Sex: neprecizat; Fragment de schelet care a aparținut unui adult, complet deranjat, probabi parțial și prin înmormântarea lui M. 33/2017. Fragmente de oase lungi și de maxilar, un omoplat etc. se aflau la dreapta defunctului precedent.

M. 35/2017 (Pl. 2/1). Orientare: V-E. Din acesta au fost găsite in situ doar tibiile și peroneele, depuse paralel. Un fragment de bazin este la craniul lui M. 33/2017. În partea lor stângă se afla un fragment de țiglă.

Resturi provenite de la un schelet sau mai multe ale unor copii au fost găsite la dreapta lui M. 33, după M. 34/2017 care ar putea fi atribuite unui alt mormânt distrus (M. 36/2017; Pl. 2/1).

\section{Moneda descoperită $(\mathrm{Pl} .2 / 2)^{10}$}

\section{Descriere}

Denar, 1527-1559, Ungaria, Ferdinand I (1526-1564)

AR, $0.10 \mathrm{~g} ; 1.20 \times 1.10 \mathrm{~mm}$.

Av. $[\ldots]$ FER $[\ldots]$

Rv. PATR[...]

Monetărie: Kremnitz [K]-B

Catalog: Huszár 935; Unger 745.a.

Denarul emis de Ferdinand I (1526-1564) descoperit în M. 33/2017 este intens uzat, sugerând o circulație îndelungată a piesei și indicând faptul că, cel mai probabil, moneda a fost retrasă din circulație chiar la momentul depunerii acesteia. Piesa monetară bătută în monetăria de la Kremnitz este comună atât în circulația monetară din Transilvania, cât și în spațiul extracarpatic de-a lungul secolului al XVI-lea, neoferind informații numismatice inedite despre această emisiune sau despre peisajul monetar local. Din păcate, în ceea ce privește cadrul cronologic, starea proastă de conservare, intervalul mare de timp în care denarii emiși de Ferdinand I (1526-1564) au circulat, precum și lipsa unor alte piese monetare în inventarul mormântului care să permită determinarea unui cadru mai elaborat, îngreunează stabilirea unui moment cât mai exact al depunerii monedei. Astfel, din punct de vedere cronologic şi raportându-ne exclusiv la moneda recuperată din acest context funerar, nu putem decât să estimăm că piesa a fost depusă după mijlocul secolului al XVI-lea.

În ceea ce privește tradiția depunerii monedelor în mormintele medievale, prezența piesei pe pieptul defunctului nu este deloc surprinzătoare, cel mai adesea, acolo unde sunt prezente, monedele fiind așezate în palmă, pe piept, în zona bazinului sau chiar în gură. Pentru spațiul transilvănean o atenție deosebită a fost acordată cercetării prezenței monedelor în necropolele medievale timpurii din secolele X-XIII ${ }^{11}$, piesele monetare medievale târzii, respectiv moderne timpurii neatrăgând încă atenția cercetătorilor. În acest context, este dificil de apreciat dacă prezența acestei piese urmează și în secolul al XVI-lea tradiția adesea invocată a „obolului lui Charon”, sau dacă urmează niște caracteristici generale așa cum se poate observa în unele cazuri în necropolele de la est de Carpați ${ }^{12}$. Este

Text redactat de către Cristiana Tătaru și Iulian Leonti.

Țiplic 2017 și bibliografia aferentă.

A se vedea Munteanu et al. 2020 și bibliografia aferentă. 


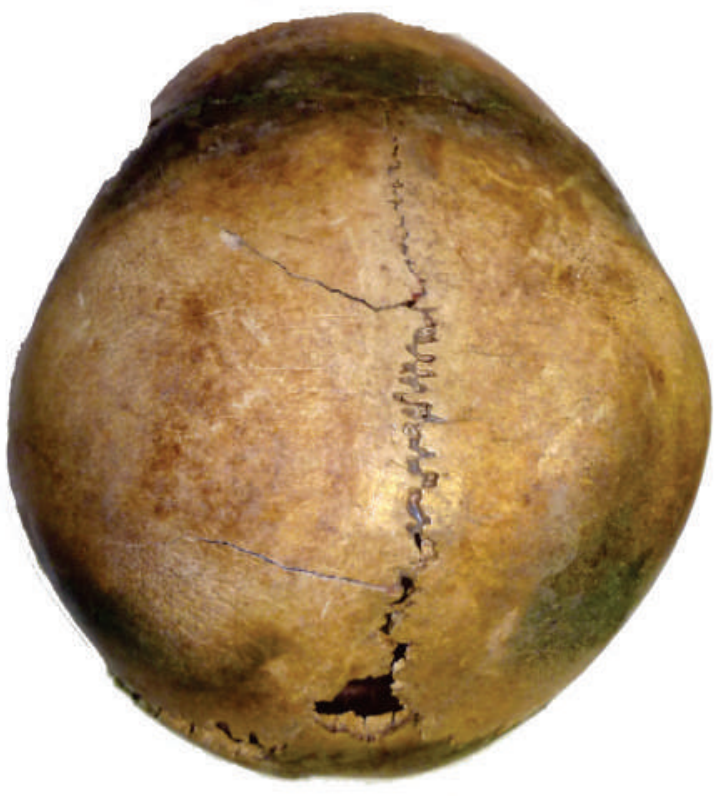

Fig. 1. Norma verticalis

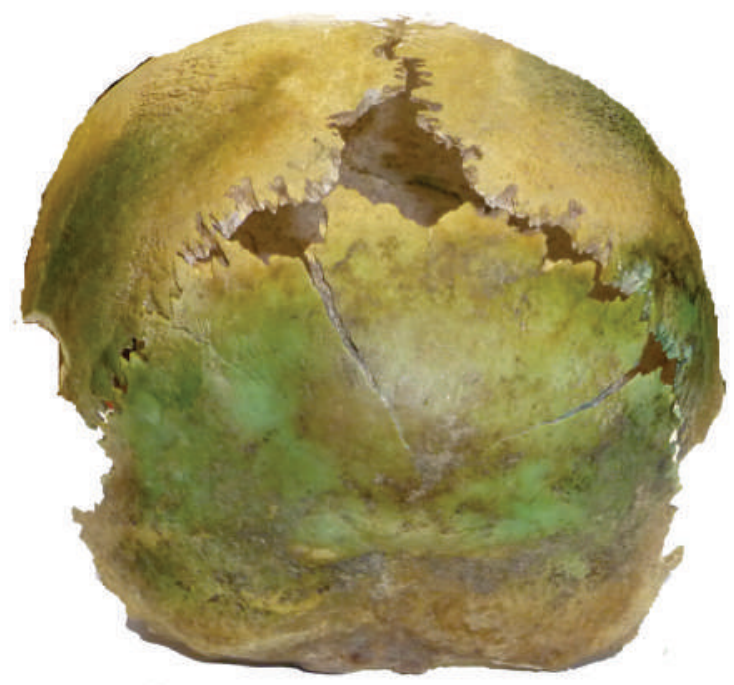

Fig. 3. Norma occipitalis

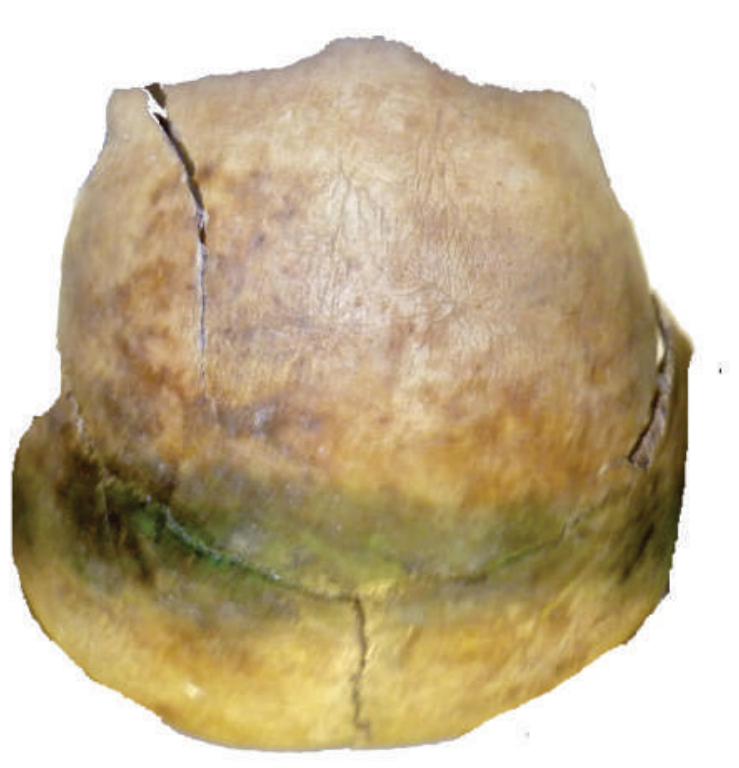

Fig. 2. Norma frontalis

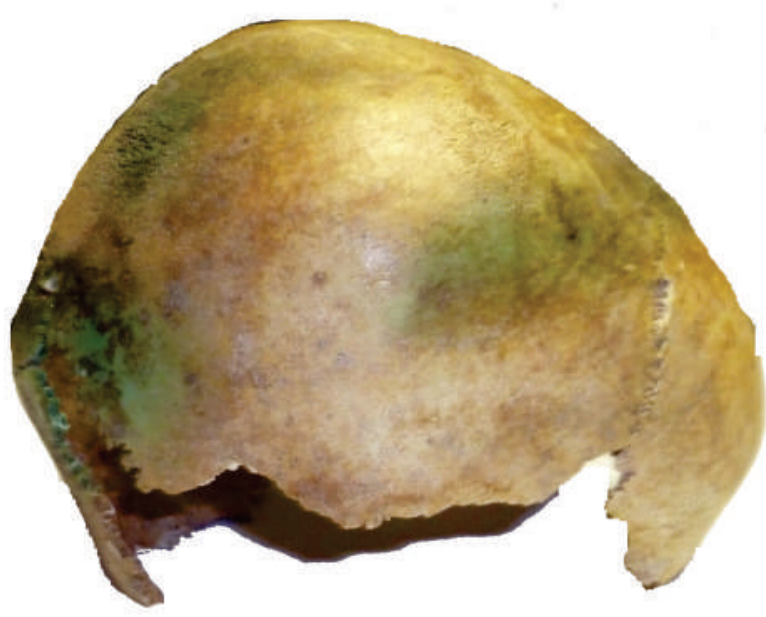

Fig. 4. Norma lateralis

de menționat faptul că un denar similar de la Ferdinand I (1526-1564), cu perforație circulară, dar depus în gura defunctului a fost descoperit în mormântul M. 5 din Cetatea Sebeșului cercetat în anul $2008^{13}$.

\section{Analiza antropologică a mormântului $33^{14}$}

Material şi metodă. Analiza antropologică se referă la materialul osteologic uman, recoltat din M. 33 de la Caransebeş-Centru ${ }^{15}$. Metodologia folosită este cea utilizată pe plan internaţional, cu caracteristicile specifice pentru categoria de vârstă la care ne referim ${ }^{16}$.

\footnotetext{
3 Popa et al. 2016, 172.

14 Text redactat de către Alexandra Comșa.

15 Cercetarea arheologică a fost efectuată de către Silviu Oţa, de la Muzeul Naţional de Istorie a României căruia îi aducem mulţumirile cuvenite, pentru că ne-a oferit posiblitatea studierii acestui material, deosebit de interesant.

16 Broca 1875, 2, 1-204; Brothwell 1981; Buikstra și Ubelaker 1994; Fazekas, 1978; Ferembach, Schwidetzky și Stloukal
} 


\section{Descriere antropologică}

Acest schelet se afla într-o stare bună de conservare, fiind reprezentat prin multe dintre componentele sale, dar lipseau clavicula stângă, o parte dintre vertebrele dorsale, humerusul stâng şi radiusul drept, ca şi oasele carpiene şi tarsiene. Desigur, la unele oase, existau şi zone deteriorate.

\section{Craniul}

Această parte a scheletului se afla în stare fragmentară dar, a putut fi reconstituită, deoarece, în general, liniile de fractură urmau traseul suturilor. Desigur, existau mici zone lipsă, în special din parietale şi din occipital, iar altele erau prezente dar, nu au putut fi ataşate la restul oaselor craniene restaurate, datorită absenței porţiunilor de continuitate.

Pe ambele parietale este vizibilă o dungă transversală de culoare brună de la un obiect, care conţinea cupru, având două proeminențe, amplasate de-o parte şi de alta a suturii sagitale, aproape de punctul bregma. Desigur, ea provine de la o bentiţă, sau o diademă. Oasele temporale sunt fragmentare, cu mastoidele de mici dimensiuni.

În norma verticalis craniul are forma sfenoidă (Fig. 1), în norma frontalis putem observa frontalul destul de bombat, caracteristic copiilor (Fig. 2), în norma occipitalis este bombă-casă (Fig. 3), iar norma lateralis nu are relevanţă prea mare, datorită deteriorării oaselor temporale (Fig. 4). Este vizibilă o deformare a craniului, foarte posibil datorată presiunii solului şi care a afectat, în special, regiunea occipitală, drept consecinţă, osul respectiv, având două crăpături evidente, situate în poziţie laterală faţă de punctul lambda, cea din dreapta la $40,57 \mathrm{~mm}$, iar cea stângă la 20,57 mm faţă de aceasta. Din cauza deformării respective, indicele cranian nu a putut fi calculat, dar, după aspectul calotei craniene, el se încadra, în mod cert, în categoria brahicrană. Pe aproape întreaga suprafaţă a occipitalului, se observă intense urme verzui, care au rezultat, desigur, în urma contactului cu un obiect care conţinea cupru.

Masivul facial era reprezentat de maxilarul superior, dar şi de mandibula acestui individ, ambele aflate în stare fragmentară. A fost recuperat şi malarul drept, acesta neputând fi ataşat la frontal, din lipsa porţiunii de continuitate. Orbitele par să fi avut forma rectangulară, cu colţurile rotunjite. Palatul avea adâncime mică şi forma elipsoidă. Fosa canina era de gradul 1, iar apertura piriforma de tip infantil. Formula dentară a acestui individ, este prezentată în continuare:

Dr.

Stg.

\begin{tabular}{|l|l|l|l|l|l|l|l|l|l|l|l|l|l|l|}
\hline & & P.2 & P.1 & C & I.2 & I.1 & & I.1 & I.2 & & P.1 & P.2 & & \\
\hline & & & $\uparrow$ & $\uparrow$ & $\uparrow$ & $\uparrow$ & & $\uparrow$ & $\uparrow$ & & & $\uparrow$ & & \\
\hline M.2 & M.1 & m.2 & m.1 & c & i.2 & i.1 & & i.1 & i.2 & c & m.1 & m.2 & M.1 & M.2 \\
\hline- & - & - & $?$ & - & $?$ & $?$ & & $?$ & $?$ & - & $?$ & $?$ & - & - \\
\hline M.2 & M.1 & m.2 & m.1 & c & i.2 & i. 1 & & i. 1 & i.2 & c & m.1 & m.2 & M.1 & M.2 \\
\hline$?$ & $\uparrow$ & $?$ & - & - & $\uparrow$ & $?$ & & $?$ & $\uparrow$ & - & - & $?$ & $\uparrow$ & $?$ \\
\hline & & & $\uparrow$ & & & & & I.1 & & & & & & \\
\hline & & & P.1 & & & & & $\uparrow$ & & & & & & \\
\hline
\end{tabular}

- dinte prezent în alveolă;

$\uparrow$ dinte aflat în procesul de erupţie;

? dinte pierdut post-mortem.

Din analiza dentiţiei, putem constata că numeroşi dinţi se aflau în procesul de erupţie, iar unii dintre cei provenind, mai ales, din dentiţia de lapte au fost pierduţi, sau găsiţi ca dinţi izolaţi, ca: 1 incisiv lateral stânga, al dentiţiei permanente, ambii canini de lapte, m.2 dreapta, ambii muguri dentari ai M.2, toţi aceşti dinţii fiind de pe maxilarul superior, apoi incisivii centrali de lapte, 1 incisiv central stânga al dentiţiei definitive, premolarul 1 dreapta, ambii canini de lapte, ambii m.1 şi ambii M.1 de pe mandibulă Molarii 1 erau erupţi, pe ambele maxilare, ceilalţi dinţi fiind în diferite stadii de dezvoltare dar, fără ca vreunul să ajungă la suprafaţa de masticaţie. M.2 exista pe maxilarul superior, sub forma mugurilor dentari, găsiţi, însă, tot ca dinţi izolaţi. Pe maxilarul inferior ei erau prezenţi, alveolele lor dentare fiind parţial închise (Fig. 5-9). 


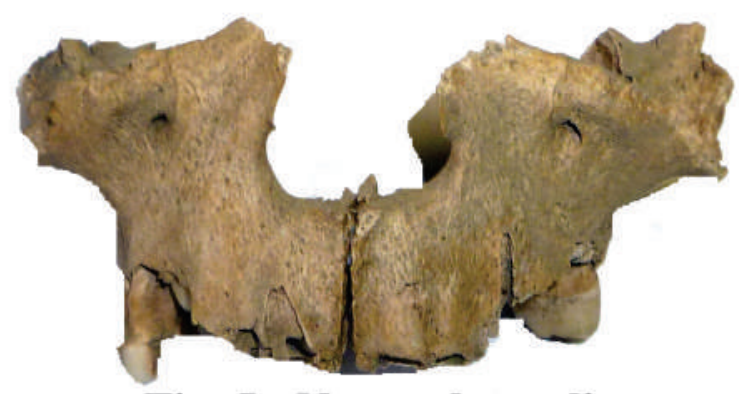

Fig. 5. Norma lateralis, vedere frontală

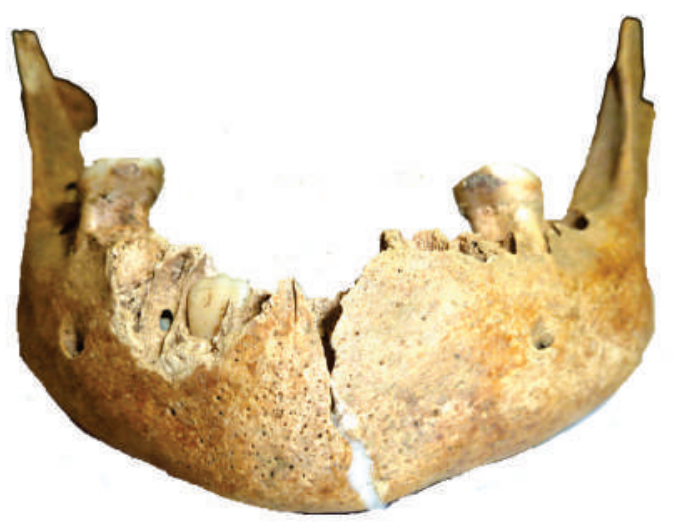

Fig. 7. Mandibula, vedere frontală

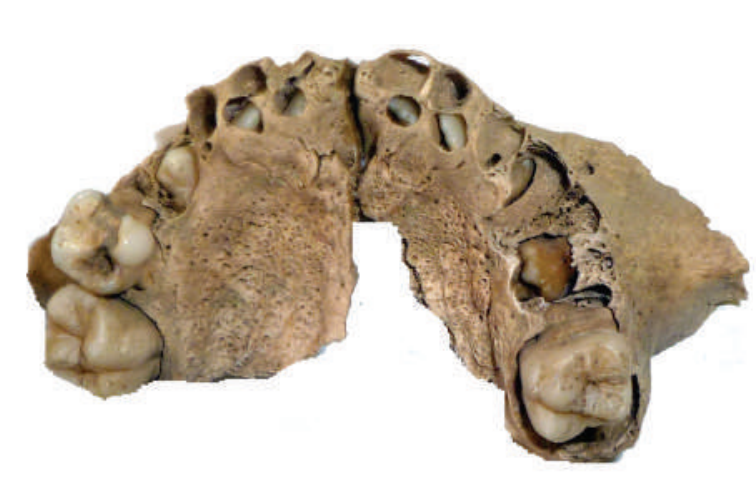

Fig. 6. Arcada dentară a maxilarului superior, vedere ocluzală

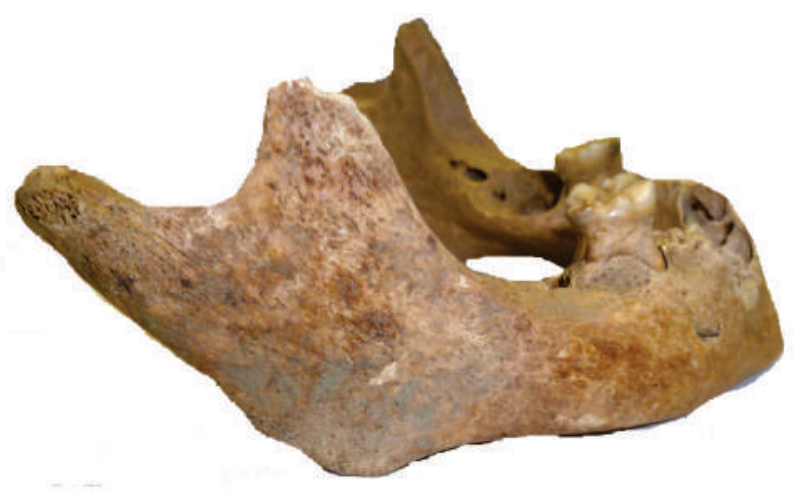

Fig. 8. Mandibula, vedere laterală

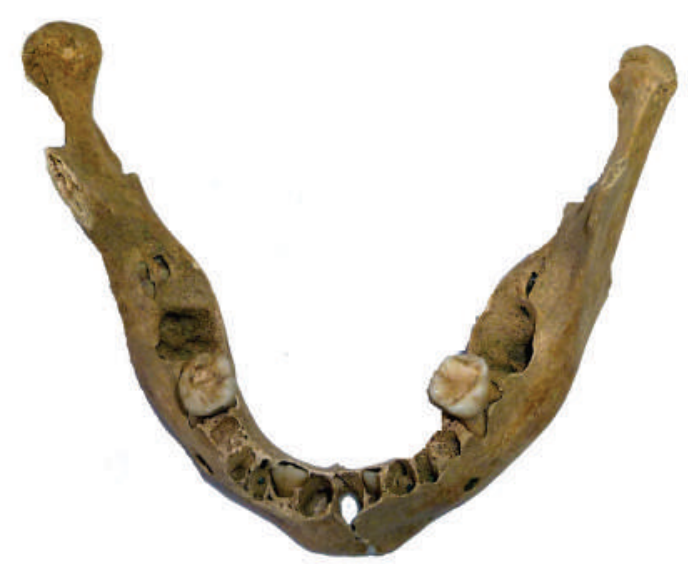

Fig. 9. Mandibula, vedere ocluzală 


\section{Scheletul post-cranian}

Din acesta au fost găsite o serie de oase, unele întregi, altele fragmentare. S-a recuperat omoplatul drept, parţial spart în zona marginii sale mediale (margo medialis, sau vertebralis). Mai exista clavicula dreaptă, fragmentară, cu capătul acromial, zona celui sternal nefiind identificată printre oasele recuperate. De asemenea, există manubriul, întreg şi 46 de porţiuni din coaste. Dintre vertebre erau 4 din zona cervicală, 6 corpuri vertebrale din zona toracică, 5 vertebre din cea lombară, 3 din cea sacrală. Există însă arcuri neurale, mai ales în stare fragmentară. S-au găsit şi 3 epifize separate de diafize dar, nu s-a putut stabili de la care oase lungi provin. Este posibil ca două dintre ele să fie de la tibii, iar 1 de la un radius. Din coxale există ambele oase iliace (Fig. 10), 1 ischion şi pubisul stâng

Dintre oasele lungi exista humerusul, ambele cubitusuri şi un radius (Fig. 11).

Lungimea maximă a diafizei lor, care serveşte şi la stabilirea vîrsei copiilor, este prezentată în tabelul de mai jos

Tabel $n r .1$ - Lungimea maximă a diafizelor oaselor lungi ale scheletului din Mormântul nr. 33. de la Caransbeş.

\begin{tabular}{|l|c|}
\hline Oasele lungi & $\begin{array}{c}\text { Lungimea maximă } \\
\text { a diafizei (mm) }\end{array}$ \\
\hline Humerus drept & 156 \\
\hline Cubitus drept & 129 \\
\hline Cubitus stâng & 126 \\
\hline Radius stâng & 115 \\
\hline
\end{tabular}
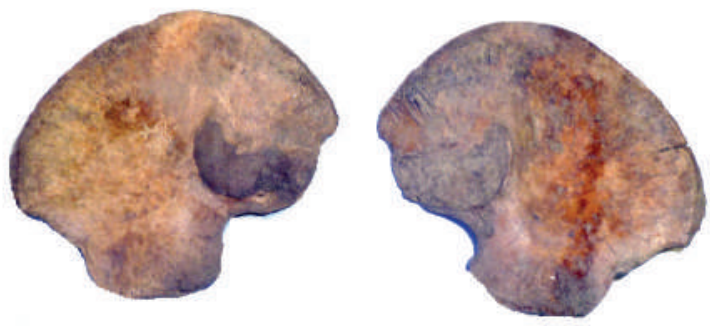

Fig. 10. Oasele iliace
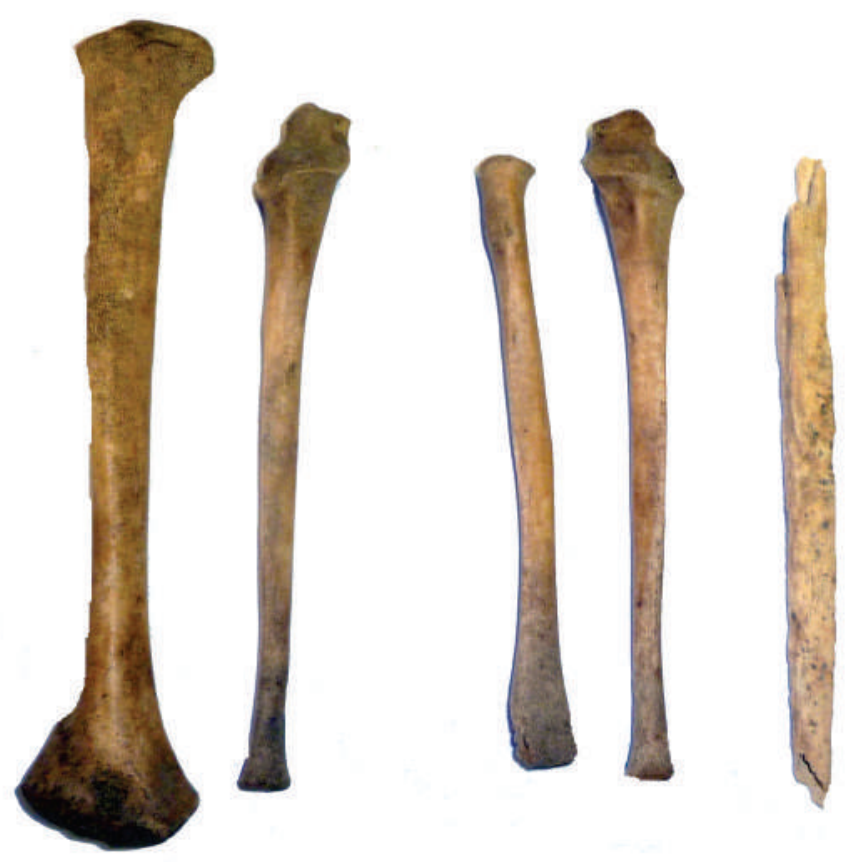

Fig. 11. Oasele lungi

\section{Diagnoza de sex şi vârstă}

Având în vedere gracilitatea generală a acestui schelet, ca şi lipsa reliefului muscular, putem aprecia că acest individ aparţine sexului feminin.

Pe baza lungimii totale a diafizelor oaselor lungi, dar şi a gradului de erupţie şi de dezvoltare a dentiţiei, pe baza schemei dentare a lui Ubelaker, putem spune că, la momentul decesului, acest copil avea vârsta de 7 ani+24 luni.

\section{Caractere non-metrice}

Pe craniul acestui individ, putem remarca absența foramenelor parietale, prezența uor oase Wormiene, demonstrată de marginile deviate ale suturii lambdoide, cel mai mare dintre ele având posibil dimensiunile de 21,31 mmx 23,10 $\mathrm{mm}$.

\section{Aspecte de patologie osoasă}

Pe calota craniană a acestui individ se remarcă existenţa hiperostozei porotice, atat exocranian, mai ales pe parietale (Fig. 12), cât şi endocranian, în acest ultim caz combinată şi cu o vascularizaţie mai intensă (Fig. 13). Pe partea superioară a orbitelor, deşi reprezentată bilateral printr-o porţiune redusă ca dimensiuni, datorită fragmentării osului, este evidentă prezența cribrei orbitalia (Fig. 14) care, însă, pare a fi în curs de vindecare, datorită închiderii parţiale a porozităţilor. Subliniem, de asemenea, obliterarea prematură şi parţială, anormală la acestă vârstă, a suturii 
coronare, de pe partea dreaptă a craniului. $\mathrm{O}$ astfel de modificare fiziologică poate fi produsă şi datorită unei boli17 . Pe maxilarul superior (în special pe suprafaţa sa anterioară, dar şi pe osul palatin), pe mandibulă (mai ales pe ramul său vertical), pe omoplaţi, pe clavicula păstrată, pe metafizele unora dintre oasele lungi, apăreau, de asemenea, numeroase porozităţi. În plus, pe corpurile vertebrelor recuperate, se aflau zone în care suprafaţa lor corticală era deteriorată, datorită osteopeniei (Fig. 15). Tot pe mandibulă, se putea remarca şi prezenţa unor mici excrescenţe osoase, în zona entezelor muşchilor maseteri şi pterigoizi. Toate aceste trăsături macroscopice enumerate, ne indică existenţa unui puternic stres fiziologic al organismului respectiv. Foarte probabil, este vorba despre un individ bolnav de scorbut, pentru care sunt frecvent identificate astfel de modificări la nivelul scheletului. Afecţiunea este numită şi boala marinarilor (din cauza faptului că ei petreceau mult timp navigând pe mare, fiind astfel lipsiţi de o alimentaţie bogată în fructe şi legume proaspete). Unele dintre manifestăile clinice ale bolii sunt hemoragia subcutanată, sau prezentă la nivelul gingiilor, retracţia lor, asociată şi cu inflamaţia, anemia feriprivă, creşterea riscului de afecţiuni cardiovasculare, reducerea imunităţii, pierderea dinţilor. La copii se remarcă diminuarea procesului de creştere, dureri musculare şi osoase, mergând până la afectarea mobilităţii individului, pete albastre şi negre pe piele, formarea de substanţă osoasă nouă subperiosteală, iritabilitate, oboseală excesivă etc. Boala este produsă de lipsa vitaminei $C$, numită şi acid ascorbic. Ea este prezentă şi în zilele noastre, afectând comunităţile cu o alimentaţie lipsită de diversitate, după cum am subliniat deja, mai ales fără legume şi fructe proaspete. Acest fapt are drept consecinţă un deficit de microelemente, şi afectează, în primul rând, femeile gravide, cele care alăptează şi copiii, astfel de persone având un organism mai sensibil la schimbările metabolice, cauzate de deficienţele nutriţionale. De asemenea, deficitul amintit se manifestă, în cazul unor fenomene, ca foametea, recoltele slabe mai îndelungate, diverse calamităţi, furtunile de durată, dependenţa de carbohidraţi, sau războiul, care şi ele, la rândul lor, împiedică asigurarea unei alimentaţii diversificate şi echilibrate. Spre deosebire de alte mamifere, care îşi pot sintetiza singure vitamina C pornind de la glucoză, organismul uman, la fel ca şi celelalte specii de primate, nu poate realiza acest proces. Astfel, necesarul de acid ascorbic poate fi asigurat doar prin aport alimentar, dintr-o serie de fructe, cum sunt cele de pădure, citricele, despre ultimele vorbind în perioada actuală sau, din legumele verzi. Vitaminele, mineralele şi oligoelementele exercită roluri fiziologice foarte importante în corpul uman, cum ar fi reglarea unor procese metabolice, menţinerea homeostaziei osoase, sinteza unor hormoni etc. Deficienţa lor joacă un rol determinant în apariţia bolilor metabolice netransmisibile. Vitamina C, de exemplu, este implicată în sinteza şi stabilizarea moleculei de colagen, dar şi în prevenirea stresuluii oxidativ al ADN-ului ${ }^{18}$. Scorbutul este determinat de un aport alimentar insuficient al vitaminei amintite, de o pierdere mai accentuată a acesteia prin metabolism, malabsorbiţie, creşterea cerinţelor organismului (cum ar fi în unele boli sau, în prezenţa paraziţilor). În cazul în care nu este tratată, boala duce rapid la decesul persoanei respective dar, poate fi prevenită uşor, prin consumul regulat de fructe şi legume, care sunt bogate în această vitamină ${ }^{19}$. În plus, în cazul unei îmbolnăviri, revenirea la starea de sănătate este rapidă, în decursul a câteva săptămâni, dacă este asigurată cantitatea zilnică necesară de acid ascorbic.

Pe teritoriul României, deși, în mod cert, această afecţiune era prezentă cu mult timp în urmă, prima atestare a ei datează din anul 1720 când, la Timişoara, medicul oficial al oraşului a constatat prezenţa scorbutului într-o tabără militară. Acolo, soldaţii consumau preponderent hrană conservată şi erau mai mult bolnavi, în timp ce ofiţerii beneficiau şi de consumul legumelor şi fructelor proaspete, neavând probleme similare de sănătate. Între anii 18021803 a fost consemnată şi o epidemie de scorbut în cadrul populaţiei, atunci fiind menţionată o primăvară foarte friguroasă, care a avut drept consecinţă obţinerea unei cantităţi de alimente reduse din punct de vedere calitativ şi cantitativ $^{20}$. Iată deci, cum se poate evidenția existența unei corelaţii strânse între mediul ambiant, hrana şi starea de sănătate a oamenilor ${ }^{21}$.

\section{Aspecte de patologie dentară}

Pe M 1 de pe hemiarcada dreaptă a mandibulei se remarcă existenţa unei carii, situată interproximal, faţă de M 2. De asemenea, un alt proces carios afectează $\mathrm{m} .2$ dreapta de pe maxilarul superior, dar şi pe $\mathrm{m} .2$ de pe hemiarcada dreaptă a osului amintit. După cum se ştie, cariile, cele mai frecvente afecţiuni dentare, se produc ca urmare a consumului mare de carbohidraţ̧i ${ }^{22}$. Incidenţa destul de mare a acestei afecţiuni la un singur individ, de vârstă foarte tânără, ne indică predominanţa unui regim alimentar bogat în astfel de substanţe, posibil specific întregii

\footnotetext{
7 Brothwell 1981, 45.

8 Snoddy et al. 2018, 876-895.

***, Scorbutul sau cât de periculos este deficitul de vitamina C, bioclinica.ro.

*** - Evoluţia bolilor la români: "De la 1700 încep marile necazuri ale poporului român", Adevărul, 23 februarie, 2011.

Pentru alte detalii privind situaţia meteorologică din perioada la care ne referim, v. Ioana Constantinescu, Evenimenţialul meteorologic, agricultura şi societatea româneasă în "secolul fanariot”, Studii şi Materiale de Istorie Medie XI, Evul mediu românesc. O nouă abordare, 1992, 21-62.

22 Roberts și Manchester 1995, 45-46.
} 


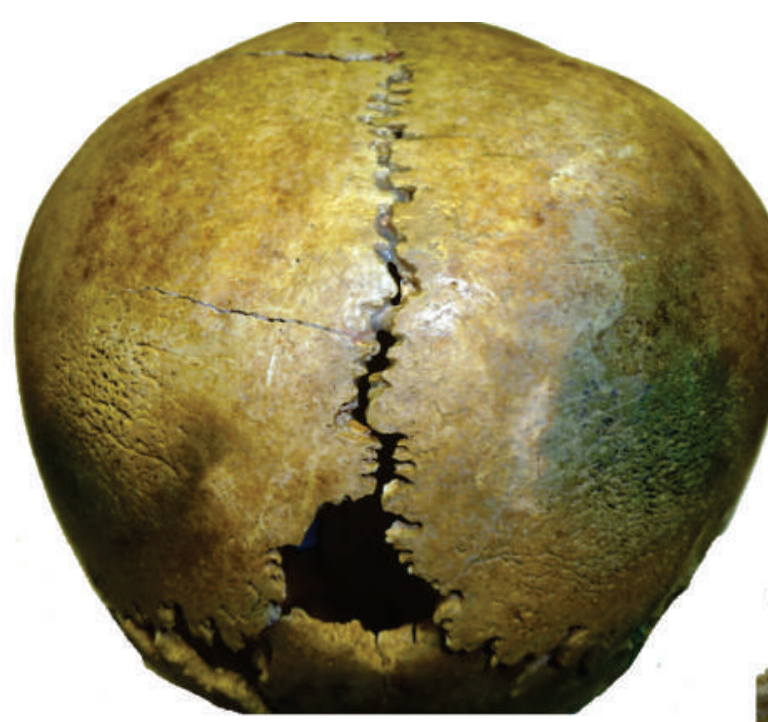

Fig. 12. Hiperostosa porotică exocraniană

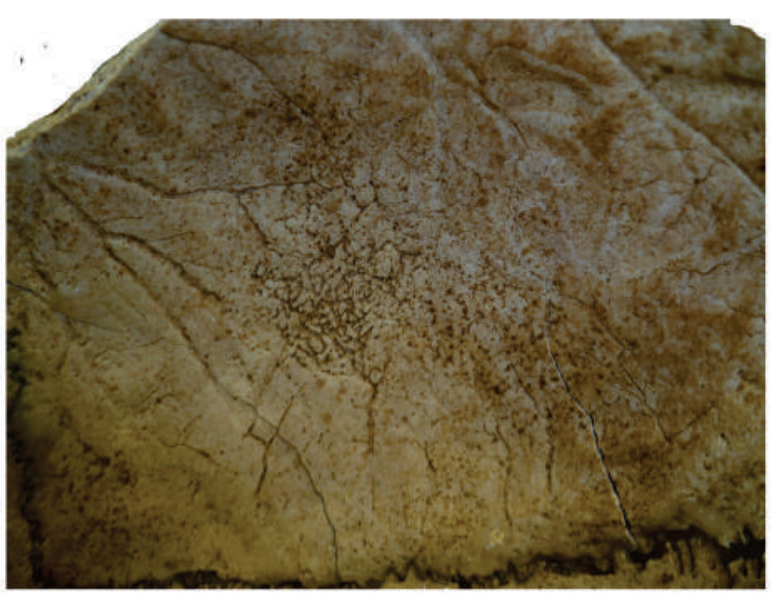

Fig.13. Hiperostosa porotică endocraniană

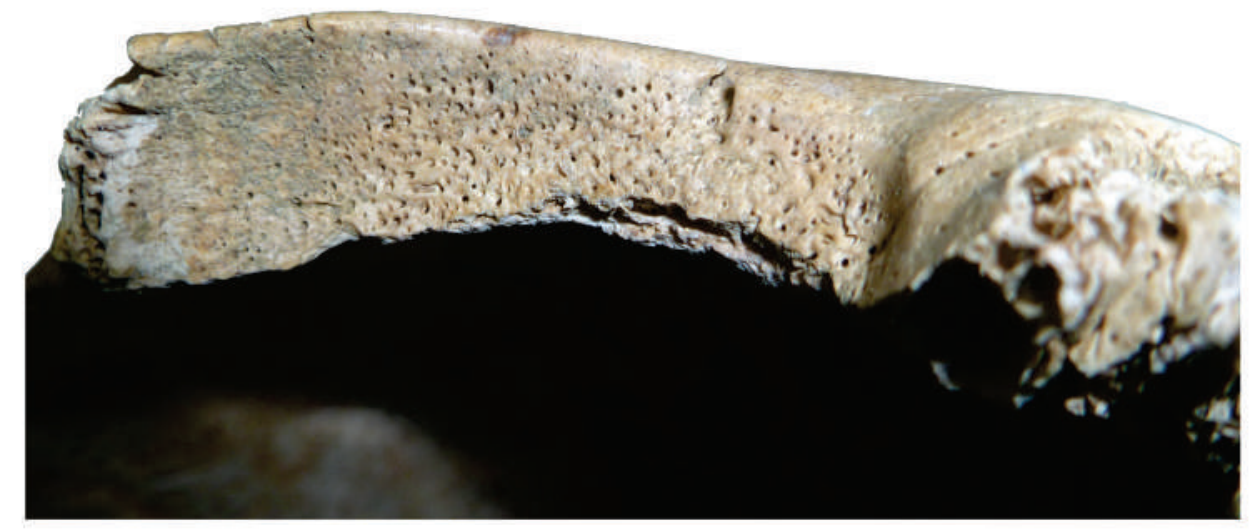

Fig.14. Cribra orbitalia
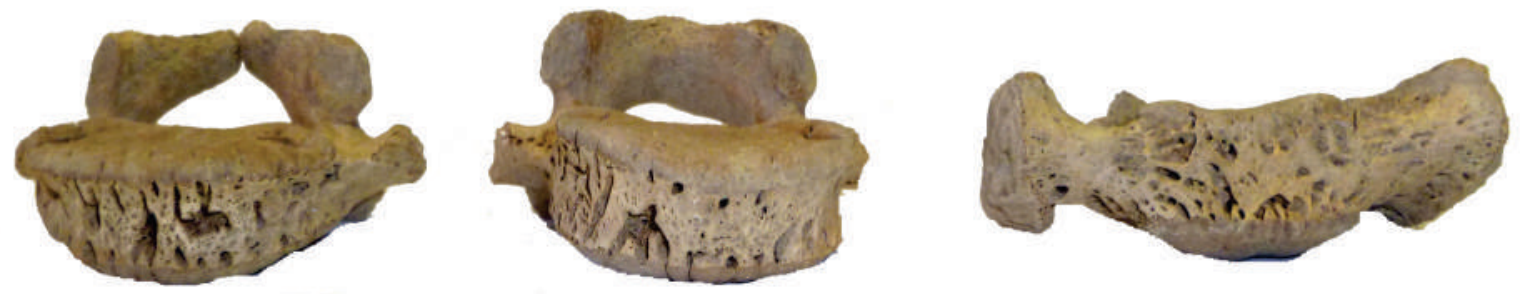

Fig.15. Vertebre cu osteopenie 
comunităţi. Mai mult decât atât, observăm că sunt afectaţi preponderent molarii m.2. Acest lucru ne indică, pe lângă faptul cunoscut, că dantura de lapte are o sensibilitate mai accentuată şi existenţa unor anumite obiceiuri alimentare specifice acestui individ.

\section{Unele concluzii antropologice.}

Scheletul studiat, ne evidenţiază o situaţie deosebit de interesantă. Înmormânarea acestei fetiţe a fost făcută cu fast, datorită obiectelor de inventar, care s-au găsit împeună cu ea. Deci, am putea să ne gândim că ea a beneficiat de o stare de sănătate bună. Totuşi, situaţia se prezintă exact invers. Datorită urmelor specifice, vizibile pe mai multe oase, este foarte posibil ca decesul ei să fi fost determinat chiar de scorbut care, aşa cum am văzut, poate duce la un astfel de exitus într-un interval scurt de timp. Nu cunoaştem exact factorul care a determinat diminuarea semnificativă a resurselor de vitamina $\mathrm{C}$ dar, putem presupune existenţa în acea vreme, a unor perioade cu fenomene meteorologice extreme, cu consecinţe nefaste asupra alimentaţiei întregii populaţii, sau doar a unui segment al acesteia. Din punct de vedere antropologic şi paleopatologic, dar şi arheologic, acesta este primul caz de scorbut, documentat, din ţara noastra.

Desigur, astfel de cazuri, sunt deosebit de importante, deoarece, prin stabilirea clară a contextului arheologic, a perioadei istorice în care se încadreaza mormântul respectiv, dar şi ca urmare a studiilor antropologic şi paleopatologic, putem dispune de date clare, care se pot aprofunda, printr-o corelaţie cu cele deja existente, referitoare la aspectele mediului ambiant al perioadei în care a fost datat scheletul respectiv, dar şi prin comparaţii cu alte informaţii oferite de morminte provenind din alte situri ale perioadei respective.

\section{Rezultatele investigaţiilor fizico-chimice efectuate pe fragmentele de bentiţă lucrata cu fir metalic din mormântul 33/2017 (cimitirul Bisericii medievale Caransebeş) ${ }^{23}$}

În vederea determinării naturii fizico-chimice a probelor de fire metalice din fragmentele de textile arheologice s-au utilizat ca metode analitice experimentale microscopia optică în lumină reflectată la măriri cuprinse între 8x 80x şi spectrometria portabilă cu fluorescenţă de raze X (pXRF). Pentru examinările şi analizele prin microscopie optică s-a folosit un stereomicroscop Nikon SMZ 1000, imaginile fiind achiziţionate cu o camera digitală DSRL Nikon D90, examinate prin live view şi analizate cu softul de imagine Nikon Camera Control Pro 2.0. Analizele nedistructive XRF s-au efectuat cu ajutorul unui spectrometru portabil cu fluorescenţă de raze X model InnovX 6000 Alpha Series, echipat cu anticatod din W şi detector tip diodă SiPIN incapsulată in vid, cu răcire prin sistem Peltier. Spectrometrul este prevăzut cu standardizare internă (analize multielement) şi un sistem de monitorizare şi control al obturatorului de raze X (PCB) format din cinci filtre montate pe blocul tubului de raze X care filtrează radiaţia X emisă de tub cu scopul optimizării condiţiilor de excitare. Analizele s-au efectuat direct pe probe în modurile de analiză Analytical Alloy (toate probele), şi respectiv Soil (proba P2). Parametrii de lucru utilizaţi au fost: $\mathrm{U}=35 \mathrm{kV}, \mathrm{I}=6 \mu \mathrm{A}$, timp de achiziţie $120 \mathrm{sec}$. (Analytical Alloy), şi respectiv, $\mathrm{U}=40 \mathrm{kV}, \mathrm{I}=7 \mu \mathrm{A}$ (elemente grele) şi $\mathrm{U}=15 \mathrm{kV}, \mathrm{I}=5.5 \mu \mathrm{A}$ (elemente uşoare), timp de achiziţie $60 \mathrm{sec}$. (Soil). Pentru evaluarea rezultatelor s-a utilizat un sistem HP iPAQ model HX2700 cu pachet soft InnovX cu subrutine de testare şi diagnosticare.

În urma examinărilor prin microscopie optică s-a observat că este posibil ca bentița copilului să fi fost lucrată dintr-un material textil de mătase albastră pe care a fost aplicată o dantelă argintie lucrată cu fire metalice din benzi strâns înfășurate în S pe miez de mătase albă nevopsită. În funcție de caracteristicile lor morfologice au putut fi observate două tipuri de fire metalice: (i) mai groase, obținute din benzi metalice mai late (laţime de aproxim. 700 - $850 \mathrm{~mm}$ ) înfăşurate pe miez de mătase mai gros răsucit în $\mathrm{S}$, și (ii) mai subțiri, din benzi metalice mai înguste (lăţime de aproxim. 500 mm) înfăşurate la fel, pe miez de mătase, dar răsucit în Z (Fig. 16).

S-a observat, deasemenea, că firele metalice din probele examinate, dar și din fragmentele mici textile, prezintă o patină subțire de culoare negru-brun închis și produşi de coroziune specifici cuprului arheologic și aliajelor din cupru care au stat timp îndelungat îngropate în pamânt, respectiv carbonaţi bazici de cupru (azurit albastru şi malachit verde), produşi de coroziune specifici zincului pulverulenți de culoare albă (oxizi, hidroxizi sau carbonați bazici de zinc), dar și produși de coroziune caracteristici argintului (oxizi sau sulfuri), precum și depuneri consistente de sol (nisip, oxizi de fier, silicaţi etc.). Majoritatea acestor produși de coroziune s-au format datorită unui mediu umed în prezenta dioxidului de carbon. Tipul solului (nisipos, calcaros, argilos lutos, nămolos, bogat în humus, pietros etc.), precum și caracteristicile acestuia (umiditate, $\mathrm{pH}$, densitate, gradul de aerare, activitatea ionilor bicarbonat, capacitatea de schimb cationic, conținutul de calciu etc.) pot determina gradul de coroziune mai scăzută sau mai avansată a metalului arheologic. Coroziunea poate fi accelerată și prin creșterea acidității solului datorită ploilor acide și poluării ${ }^{24}$.

\footnotetext{
23 Text redactat de Zizi Baltă.

24 Scott 2002, 35-42.
} 

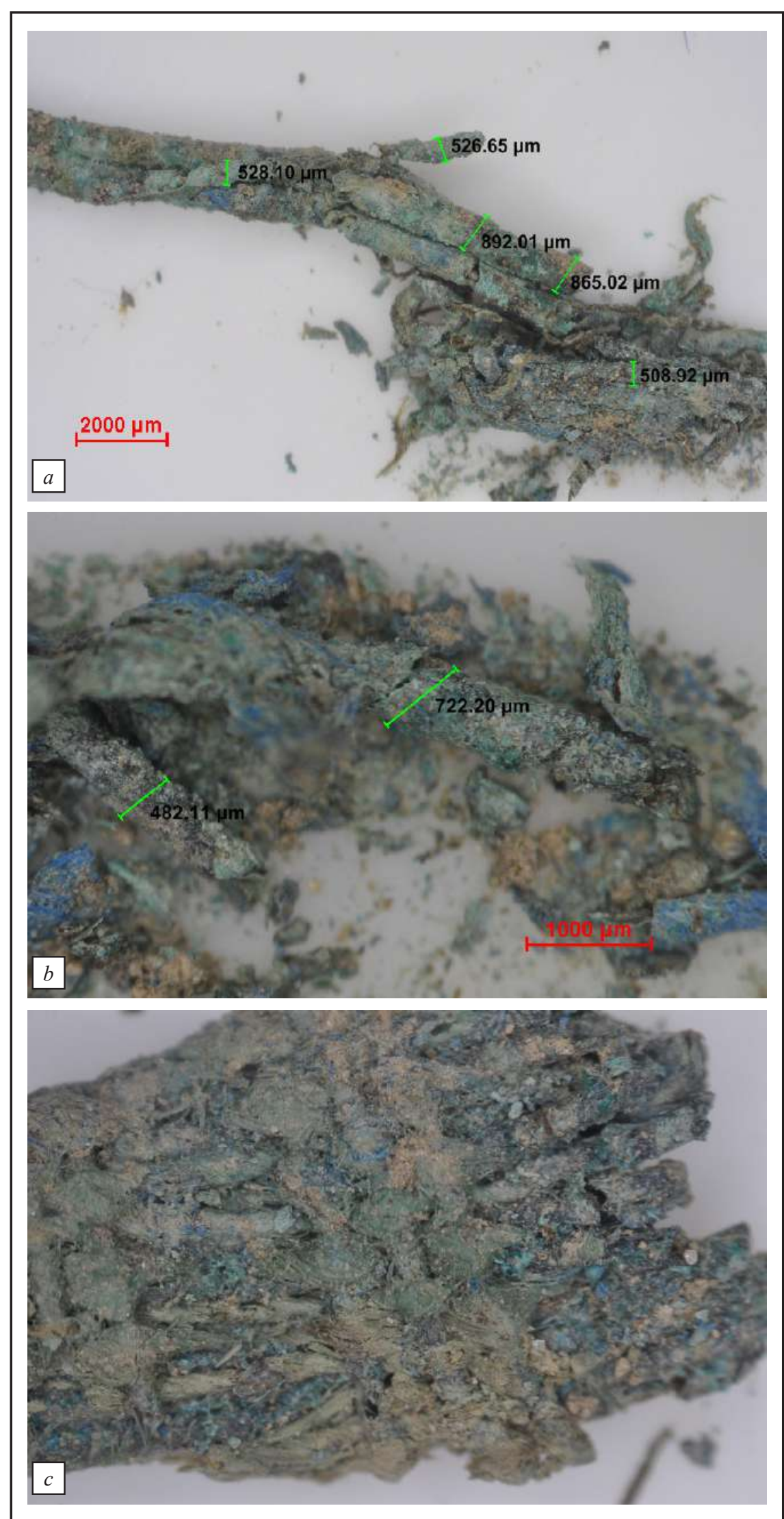

Fig. 16. Imaginile probelor P5, P11 si P12 examinate prin microscopie optică în lumina reflectată: a) P11 (mărire de 10x), b) P12 (30x) și c) P5 (20x). In imaginea c) se observă că, în unele zone, banda metalică s-a rupt și s-a desprins rămânând vizibil miezul textil de mătase albă, nevopsită și răsucită în $Z$. 

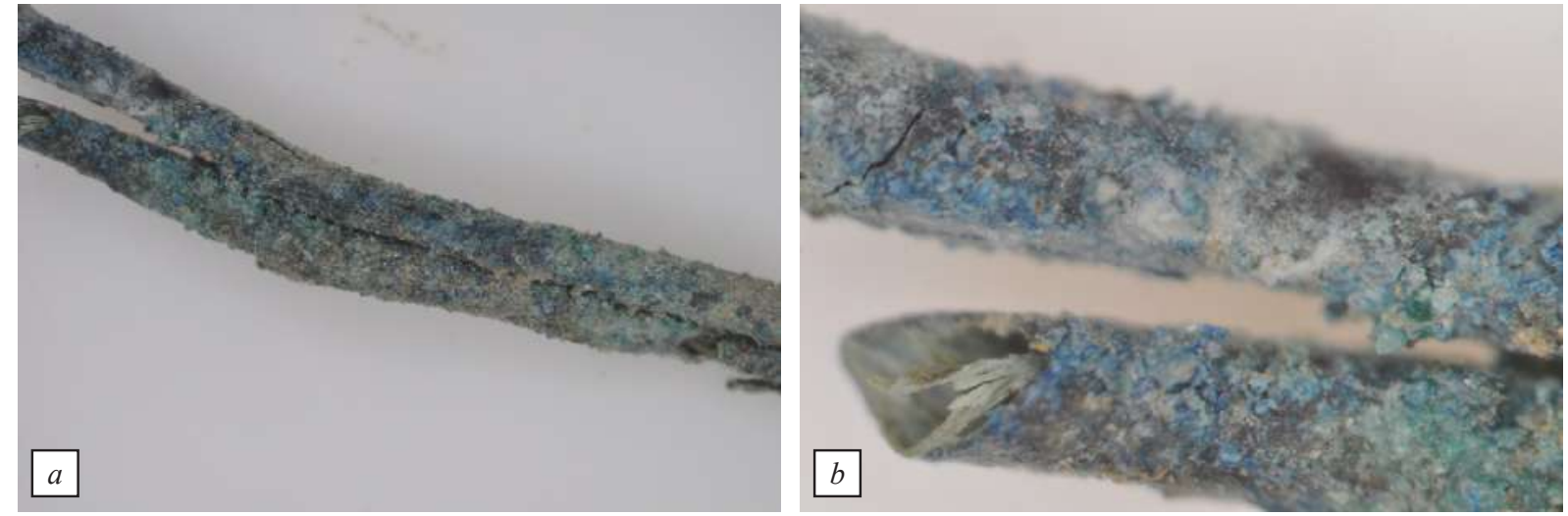

Fig. 17. Imaginea probei P1 în lumină reflectată cu mărire de: a) 20x si b.) 60x. Este vizibil miezul textil de mătase albă nevopsită pe care a fost înfașurată bandă metalică, iar pe suprafața metalică a firelor, produșii de coroziune albaștri și verzi specifici cuprului, produșii de coroziune albi pulverulenți ai zincului (imaginea b), precum și depunerile de sol (imaginea a).

În urma analizelor XRF au putut fi determinate compozițiile elementelor constituente ale firelor metalice din bentiţa arheologică, obținându-se astfel informații interesante cu privire la materialele utilizate și tehnologia de obținere a acestora (rezultatele analizelor sunt prezentate în Tabelul nr. II).

Astfel, a rezultat că majoritatea firelor metalice au fost produse din alamă argintată, alama având un conținut mai mic de $20 \%$ de zinc în compoziție. În literatura de specialitate, acest tip de alamă este numită alamă roșie, este moale și prezintă o maleabilitate ridicată putând fi trasă în foi sau fire, de aceea este folosită în principal pentru argintare și/ sau aurire ${ }^{25}$. Există indicii că această alamă a fost produsă îndeosebi în perioada medievală și post

Tabel nr. II. Rezultatele analizelor XRF efectuate pe probele de fire metalice și fragmente textile cu fire metalice din bentița copilului. Concentrațiile elementelor constituente din probele analizate sunt exprimate în \% (Analytical Alloy), şi respectiv în ppm (Soil) pentru probele P1 și P2.

\begin{tabular}{|c|c|c|c|c|c|c|c|c|c|}
\hline Proba & Mode & $\mathrm{Ti}$ & $\mathrm{Mn}$ & $\mathrm{Fe}$ & $\mathrm{Ni}$ & $\mathrm{Cu}$ & $\mathrm{Zn}$ & $\mathrm{Ag}$ & $\mathrm{Pb}$ \\
\hline P1avers - fire metalice & Analytical & & & 0.71 & 0.11 & 9.42 & 18.64 & 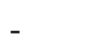 & 1 \\
\hline $\begin{array}{l}\text { lrevers (cu depuneri sol) - fire } \\
\text { etalice }\end{array}$ & Analytical & & & 0,51 & 0.07 & 87.06 & 11.36 & - & 0.99 \\
\hline 2 - fragment textil cu fire metalice & Analytical & & 0.03 & 0.43 & 0.1 & 94.25 & נס. & .28 & 0.08 \\
\hline 3 - fragment textil cu fire metalice & Analytical & 0.18 & 0.04 & 1.33 & 0.11 & 91.49 & 5.56 & 1.21 & 0.09 \\
\hline P4 - fragment textil cu fire metalice & Analytical & 0.19 & 0.05 & 1.01 & 0.12 & 94.18 & 4.31 & - & 0.15 \\
\hline P5 - fragment textil cu fire metalice & Analytical & 0.13 & & 0.57 & 0.08 & 93.68 & 3.9 & 1.5 & 0.15 \\
\hline P6 - fragment textil cu fire metalice & Analytical & 0.12 & 0.05 & 0.65 & 0.13 & 92.81 & 4.91 & 1.22 & 0.11 \\
\hline P7 - fragment textil cu fire metalice & Analytical & & & 0.71 & 0.14 & 93.61 & 5.42 & - & 0.13 \\
\hline P8 - fragment textil cu & Analytical & 0.16 & 0.04 & 1.22 & 0.13 & 93.33 & 3.55 & 1.49 & 0.07 \\
\hline P11 - fire metalice & Analytical & 0.14 & & 0.49 & 0.07 & 86.75 & 11.8 & - & 0.76 \\
\hline 1 & Soil & \multicolumn{8}{|c|}{$\begin{array}{l}\mathrm{Cu}>10 \%, \mathrm{Zn}>10 \%, \mathrm{Fe}=26083 \mathrm{ppm}, \mathrm{Pb}=2300 \mathrm{ppm}, \mathrm{Ca}= \\
49777 \mathrm{ppm}\end{array}$} \\
\hline P2avers & Soil & \multicolumn{8}{|c|}{$\begin{array}{l}\mathrm{Cu}>10 \%, \mathrm{Zn}=55498 \mathrm{ppm}, \mathrm{Ag}=3409 \mathrm{ppm}, \mathrm{Fe}=20227 \\
\text { ppm, } \mathrm{P}=17206 \mathrm{ppm}, \mathrm{S}=4592 \mathrm{ppm}, \mathrm{Ca}=48444 \mathrm{ppm}, \mathrm{Pb} \\
=257 \mathrm{ppm}\end{array}$} \\
\hline P2revers (c & Soil & \multicolumn{8}{|c|}{$\begin{array}{l}\mathrm{Cu}>10 \%, \mathrm{Zn}=29535 \mathrm{ppm}, \mathrm{Ag}=4074 \mathrm{ppm}, \mathrm{Fe}=50576 \\
\mathrm{ppm}, \mathrm{P}=13842 \mathrm{ppm}, \mathrm{Ca}=46117 \mathrm{ppm}, \mathrm{K}=22053 \mathrm{ppm}, \mathrm{Pb} \\
=204 \mathrm{ppm}\end{array}$} \\
\hline
\end{tabular}

25 Day 1991. 
medievală prin procesul de cementare cu calamină descris de preotul german Teophilus în secolul al XII-lea ${ }^{26}$, dar şi de Biringuccio în secolul al XVI-lea în tratatul său „De la Pirotechnia”27.

Metoda medievală de obținere a alamei prin cementare, cunoscută și utilizată de romani dar și de bizantini, consta în turnarea cuprului topit peste calamina calcinată (minereu bogat în zinc cu impurități de plumb și fier) și cărbune într-un creuzet închis până când se obțineau vapori de zinc care reacționau cu cuprul. La temperatura cuprului topit, cărbunele reducea oxidul de zinc la zinc metalic care se dizolva în cupru. Conținutul maxim de zinc în aliajul rezultat era controlat de presiunea de vapori a zincului din cuprul topit, aceasta fiind determinată de temperatură ${ }^{28}$. În tratatele lor tehnice din secolul al XVI-lea, Biringuccio, Ercker și Agricola descriu diferite variante ale acestei metode, concluzionând la sfârșit, că cuprul devine mai greu pe măsură ce se transformă în alamă și mai galbenauriu cu cât se adaugă suplimentar mai multă calamină, dovedind astfel o înțelegere mai aprofundată a adevăratei naturi a procesului ${ }^{29}$. Există indicii arheologice și istorice conform cărora în perioada medievală, exista o producție

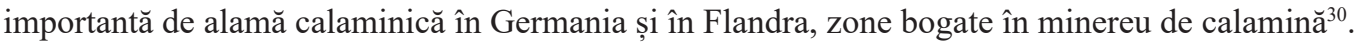

În cazul probelor în care nu a putut fi detectat argintul, s-a observat că pentru firele metalice P1 si P11, cantităţile de zinc sunt mai mari, pentru fragmentele textile mici cu fire metalice P4 și P7, rezultând concentrații de zinc similare cu ale fragmentelor textile în care a fost identificată prezenţa argintului. În plus, în urma analizelor XRF, modul de analiză Soil, efectuate pe proba P2, a rezultat pentru suprafața cu depuneri consiste de sol (P2revers) o cantitate mai mică de zinc decât în cazul suprafeței acoperite în principal cu produși de coroziune ai cuprului (P2avers).
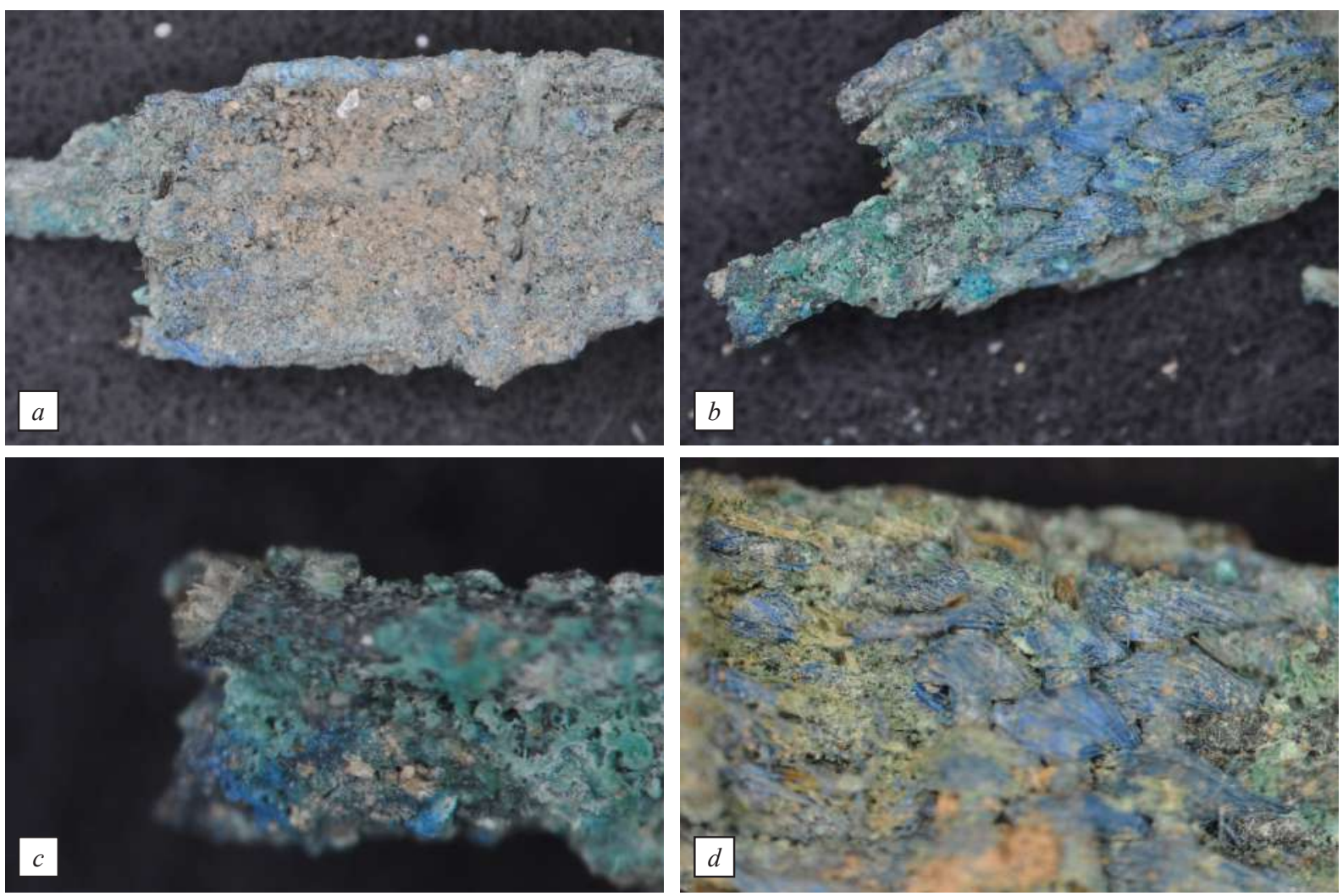

Fig. 18. Imaginile probei P2 - fragment textil cu fire metalice în lumina reflectată: a) P2 revers cu depuneri consistente de sol, mărire de 20x; b) P2 avers, mărire 20x; c) P2 avers cu produşi de coroziune ai cuprului (azurit albastru $\mathrm{Cu} 3(\mathrm{OH}) 2(\mathrm{CO} 3) 2$ instabil care, în prezența apei, s-a transformat în malachit verde Cu2(OH)2CO3), produşi ai zincului, posibil și ai argintului, mărire $60 x$; d) $P 2$ avers, mărire $30 x$ - țesătura din mătase albastră cu fire metalice corodate, resturi umane (piele, păr) și depuneri de sol înglobate în probă.

\footnotetext{
26 Presbyter 1979, 143-145.

27 Smith și Teach Gnudi, 1990, 54-114.

28 Craddock 2009, 147.

29 Craddock și Eckstein 2003, 226-227.

30 Smith și Teach Gnudi 1990, 123-150.
} 
Cantitățile mari de zinc identificate în unele probe, pe suprafețele fără depuneri consistente de sol, sugerează o prezență mai mare a produșilor de coroziune ai zincului formați pe suprafața metalică, alături de produșii de coroziune caracteristici cuprului și, în unele cazuri și ai argintului (au fost detectate prin XRF sulfuri în cazul probei P2avers soil) $)^{31}$. Fosforul a fost de asemenea identificat în proba P2 sugerând prezența unor resturi umane (piele, păr) vizibile și în unele imagini de microscopie (Fig. 18d și Fig. 19b).

Conținutul de zinc din alamă poate fi considerat ca fiind un bun indicator cronologic $^{32}$. În funcție de conținutul în zinc al firelor metalice din fragmentele textile arheologice $(\mathrm{Zn}<$ $20 \%$ ), se poate presupune că bentiţa copilului este din secolul al XVI-lea, cunoscut fiind din literatura de specialitate că alamele cu zinc mai mare de $20 \%$ în compoziție încep să apară spre sfârșitul secolului al XVI-lea, ca urmare a dezvoltării și utilizării pe scară largă a procesului de cementare a cuprului topit
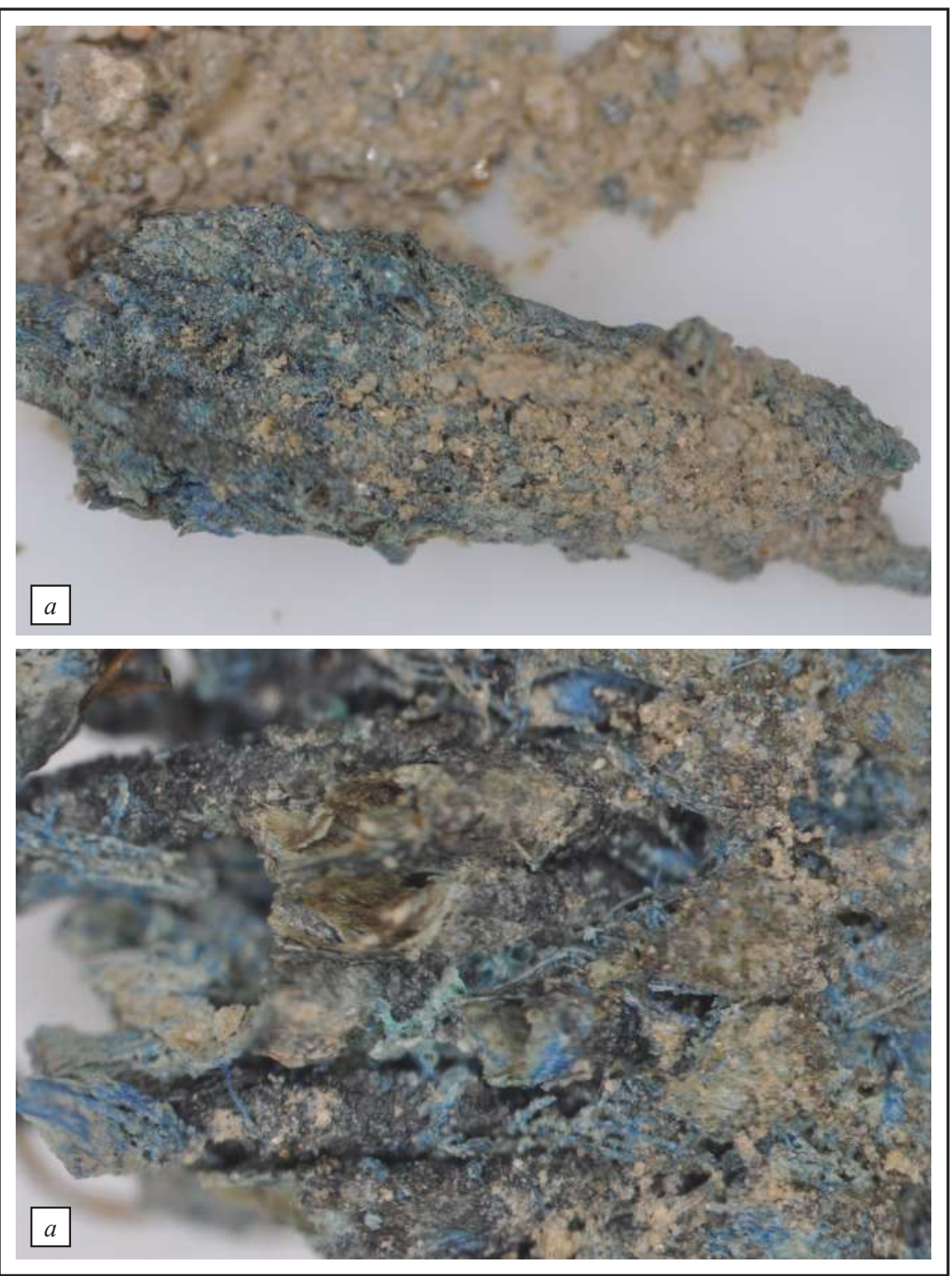

Fig. 19. Imaginile de microscopie în lumină reflectată ale probelor: a) P4 revers cu depuneri consistente de sol (mărire 15x), și b) P9 avers (mărire 40x) cu resturi umane (posibil păr) înglobate în probă, metalul pare să fi fost ars.

cu calamină $\breve{a}^{33}$. De-abia spre sfârșitul secolului al XVII-lea încep să se producă alame cu conținut mai mare de $33 \%$, datorită utilizării metodei de aliere a cuprului cu zincul metalic brut (spelter) obținut prin simpla reducere a calaminei cu cărbune, proces numit și speltering ${ }^{34}$.

\section{Concluzii}

Poziția mormântului 33/2017 în cadrul necropolei din centrul oraşului Caransebeș, indică faptul că înmormântări s-au făcut și în zona de sud a bisericii, mai departe decât fostele casete cunoscute din vechile săpături. Descoperirea și a altor complexe funerare la o distanță chiar mai mare, demonstrează că cimitirul a fost mult mai mare, el extinzându-se cel puțin până spre marginea actuală a șoselei.

În jurul mormântului mai existau altele aparținătoare tot unor copii, dar și fragmente de schelete ale unor indivizi adulți. Din păcate, starea fragmentară a scheletelor din apropiere precum și lipsa unor analize ADN, ne împiedică

\footnotetext{
CCI Notes 4/ 1 Identifying Archaeological Metal, Canadian Conservation Institute 2007, 2.

Craddock 2009, 147.

33 Craddock 2009, 147-149.

34 Craddock 2009, 148-149.
} 
să putem preciza dacă este vorba de indivizi proveniți din aceeași familie sau nu. Foarte probabil nu este vorba de un loc destinat la un moment dat îngropării copiilor, deoarece deranjările de schelete s-au produs mai degrabă ca urmare a unor înhumări succesive. Orientarea diferită a oaselor provenite de la fragmentele de schelete sugerează că înmormântările au avut loc la momente diferite din an. De asemenea, orientarea bisericii nu parte să fi avut vreo importanță prea mare pentru cei care au făcut gropile în care au depus defuncții.

Prezența sicriului realizat pentru un copil constituie un lucru mai puțin obişnuit pentru necropolele medievale, chiar și din veacul al XVI-lea. Aceasta demonstrează că foarte probabil el a aparținut unor persoane înstărite din oraș, probabil nobili sau comercianți cu posibilități materiale destul de importante. Prezența unor elemente de la o piesă textilă din mătase, provenită din import, țesută inclusiv cu fir argintat confirmă supoziția anterioară.

Analizele realizate pe fragmentele textile indică nu doar compoziția și modul de realizare, dar şi proveniența lor, precum şi perioada cronologică în care au fost comercializate.

Prezența monedei confirmă orientativ perioada în care s-a produs decesul și confirmă rezultatele analizelor materialului textil.

Chiar dacă inventarul mormântului nu este extrem de bogat, comparativ cu cel a unei bune părți a celorlalte complexe funerare, el vine să arate și produsele comercializate în zonă. Venind cel mai probabil din Europa Centrală, putem observa că la Caransebeș se aduceau nu doar mărfuri dinspre Balcani. Dacă piesa vestimentară a ajuns în oraș prin comerțul localnicilor sau a fost adusă în alte împrejurări din un alt centru este dificil de spus. Cercetările viitoare vor putea să clarifice acest aspect, în cazul în care în săpăturile arheologice de aici vor mai fi descoperite și alte piese similare.

\section{Illustrations}

\section{Tables}

Tabel no. 1 - Maximal length of the long bones belonging to the Skeleton no. 33 from Caransebes.

Table no. II - Results obtained by X-ray fluorescence analysis (XRF) on samples of metal threads and textile fragments with metal threads from the child's headband. Concentrations of the constituent elements in the analyzed samples are expressed in wt.\% (Analytical Alloy mode), and, in the case of samples P1 and P2, in ppm (Soil mode).

\section{Plates}

PI. I. 1. Location of the town of Caransebeș; 2. Location of the cemeteries dated to $11^{\text {th }}-12^{\text {th }}$ and $14^{\text {th }}-16^{\text {th }}$ centuries and of the church on the plan of Caransebeș at the beginning of the $18^{\text {th }}$ century (according to O. Onci, https://issuu. com/piaonci/docs/podrumul_lui_homolka; accessed 16.05.2019).

PI. II. 1. Plan of the area with disturbed children graves; 2/1-b. Coin issued during Ferdinand I reign (1526-1564); 3. Image of the medieval church, with the area of children graves (photo Adrian Ardeț).

PI. III. 1. Grave 33/2017. Photo during the excavation; 2. Graves 33, 34, 35/2017; 3. Detail of the upper part of grave 33/2017; 4. Grave 35/2017 and disparate bones from other burials (photo Silviu Oța).

\section{Figures}

Fig. 1. Norma verticalis of the child skull from Burial no. 33, discovered in the Medieval Church from Caransebeş, Caraş-Severin County.

Fig. 2. Norma frontalis of the child skull from Burial no. 33, discovered in the Medieval Church from Caransebeş, Caraş-Severin County.

Fig. 3. Norma occipitalis of the child skull from Burial no. 33, discovered in the Medieval Church from Caransebeş, Caraş-Severin County.

Fig. 4. Norma lateralis of the child skull from Burial no. 33, discovered in the Medieval Church from Caransebeş, Caraş-Severin County.

Fig. 5. Maxilla of the child from Burial no. 33, discovered in the Medieval Church from Caransebeş, CaraşSeverin County - frontal view.

Fig. 6. Dental arch of the maxilla, belonging to the skull of the child in Burial no. 33, discovered in the Medieval Church from Caransebeş, Caraş-Severin County - occlusal view. 
Fig. 7. Mandible of the child skeleton in Burial no. 33, discovered in the Medieval Church from Caransebeş, Caraş-Severin. County - frontal view.

Fig. 8. Mandible of the child skeleton in Burical no. 33, discovered in the Medieval Church from Caransebeş, Caraş-Severin County.- lateral view.

Fig. 9. Mandible of the child skeleton in Burial no. 33, discovered in the Medieval Church from Caransebeş, Caraş-Severin County.- occlusal view.

Fig. 10. Iliac bones of the child skeleton in Burial no. 33, discovered in the Medieval Church from Caransebeş, Caraş-Severin County.

Fig. 11. Long bones of the child skeleton in Burial no. 33, discovered in the Medieval Church from Caransebeş, Caraş-Severin County.

Fig. 12. Exocranial porotic hyperostosis, at the child skull from Burial no. 33, discovered in the Medieval Church from Caransebeş, Caraş-Severin County.

Fig. 13. Endocranial porotic hyperostosis, at the child skull from Burial no. 33, discovered in the Medieval Church from Caransebeş, Caraş-Severin County.

Fig. 14. Cribra orbitalia at the child skull from Burial no. 33, discovered in the Medieval Church from Caransebeş, Caraş-Severin County.

Fig. 15. Vertebrae with osteopenia at the child skeleton in Burial no. 33, discovered in the Medieval Church from Caransebeş, Caraş-Severin County.

Fig. 16. Images of the samples $P 5, P 11$ and $P 12$ analyzed by optical microscopy in reflected light: a) P11 (at 10x magnification), b) P12 (30x) and c) P5 (20x). In image c) could be seen that, on some areas, the metal strip is broken and flaking off, leaving visible the white undyed silk yarn core twisted in $\mathrm{Z}$.

Fig. 17. Optical microscopy image of sample P1 in reflected light at a magnification of: a) 20x and b) 60x. On the metal wire's surface are visible the blue and green corrosion products specific to copper, the powdery white corrosion products of zinc (image b), as well as soil deposits (image a), and also the white undyed silk yarn core on which metal thread has been wrapped around.

Fig. 18. Microscopy images of sample P2 - archaeological textile fragment with metal threads embedded in it, in reflected light: a) P2 revers with consistent soil deposits, at 20x magnification; b) P2 avers, at 20x magnification; c) P2 avers on which the corrosion products of copper are visible (the blue azurite $\mathrm{Cu}_{3}(\mathrm{OH})_{2}\left(\mathrm{CO}_{3}\right)_{2}$ unstable which, in the presence of water, turned into the green malachite $\mathrm{Cu}_{2}(\mathrm{OH})_{2} \mathrm{CO}_{3}$ ), corrosion products of zinc, and, possibly also, of silver, at 60x magnification; d) P2 avers, 30x magnification - the blue silk textile fabric with corroded metal wires, human remains (skin, hair) and soil deposits embedded in the sample could be clearly observed.

Fig. 19. Microscopy images in reflected light of the samples: a) P4 revers with some consistent soil deposits (at 15x magnification), and b) P9 avers (at 40x magnification) with human remains (possibly hair) embedded in the sample, also metal appears to have been burned.

\section{BIBLIOGRAFIE}

Bona P. 1993. Biserica medievală din Caransebeş. Caransebeș: Muzeul Județean de Etnografie și al Regimentului de Graniță Caransebeș.

Broca P. 1875. Instructions craniologiques et craniométriques. Mémoires de la Société d'Anthropologie de Paris 2: 1-204.

Brothwell, D. R. 1981. Digging up bones. The excavations, treatment and study of human skeletal remains. Ithaca, New York: Cornell University Press.

Buikstra, J. E. and Ubelaker, D. H. 1994. Standards for Data Collection from Human Skeletal Remains. Arkansas Archaeological Survey. Research Seminar 44, Fayetteville.

Constantinescu, I. 1992. Evenimenţialul meteorologic, agricultura şi societatea româneasă în "secolul fanariot". Studii şi Materiale de Istorie Medie XI, Evul mediu românesc. O nouă abordare: 21-73.

Craddock, P.T. și Eckstein, K. 2003. Production of Brass in Antiquity by Direct Reduction, în P.T. Craddock şi J. Lang (ed.) Mining and Metal Production through the Ages. London: British Museum: 226-227.

Craddock, P. 2009. Scientific Investigation of Copies, Fakes and Forgeries. Oxford: Butterworth-Heinemann Elsevier Ltd.,UK. 
Day, J. 1990. Brass and Zinc in Europe from the Middle Ages until the $19^{\text {th }}$ century, în Craddock, P.T. (ed.) 2000 Years of Zinc and Brass, London: British Museum: 123-150.

Day, J. 1991. Copper, Zinc and Brass Production, în J. Day and R. F. Tylecote (ed.), The Industrial Revolution in Metals. London: The Institute of Metals.

Fazekas, I. Gy. și Kósa, F. 1978. Forensic fetal osteology. Budapest: Akadémiai Kiadó.

Ferembach, D, Schwidetzky, I. și Stloukal, M. 1979. Recommandations pour detérminer d'âge et le sexe sur le squelette. Bulletin et Mémoires de la Societé d'Anthropologie de Paris, t. 6, serie XIII: 7-45.

Groza, L. 1993. Cetatea Caransebeș - Câteva precizări cronologice. Banatica 12, II: 89-99.

Huszár L. 1979. Münzkatalog Ungarn: Von 1000 bis Heute. München: Battenberg Verlag.

Iaroslavschi, E. 1975. O villa rustica la Caransebeş. Banatica 3: 355-363.

Krogman, W. M. 1962. The Human Skeleton, in Forensic Medicine. Springfield Illinois: Charles C. Thomas Publisher.

Lewis, M. E. 2018. Children in Bioarchaeology. Methods and Interpretations, in Biological Anthropology of the Human Skeleton: 119-143. New York: Academic Press.

Munteanu, L., Honcu, Șt. și Aparaschivei D. 2020. Descoperiri monetare din necropola bisericii „Talpalari” din Iași. Revista de Arheologie, Antropologie și Studii Interdisciplinare 2: 273-286.

Niedermaier, P. 2004. Stadtebau im Spatmittelalter. Siebenburgen, Banat und Kreischgebiet. 1348-1542. KölnWeimar-Wien: Böhlau.

Olivier G. 1969. Practical anthropology. Michigan, Springfield, III: Charles C. Thomas Publisher.

Oța, S. și Ardeț, A. 2018. Câteva observații privind necropola de la Caransebeș-Centru, faza timpurie (secolele XI-XII). Cercetări Arheologice 25: 205-214, https://doi.org/10.46535/ca.25.09.

Oța, S. 2019. Brățări bizantine și post bizantine din metal și sticlă descoperite la nordul Dunării de Jos. Context, modele, cronologie (secolele XI-XII/începutul secolului al XIII-lea). Cercetări Arheologice 26: 219-242, https://doi.org/10.46535/ca.26.08.

Oța, S., Ardeț, A. și Negrei, D. 2020. The medieval cemeteries from the territory of the present-day city of Caransebeș, în S. Krznar, T. Sekelj Ivančan, J. Belaj, T. Tkalčec (eds.) Zbornik Instituta za Arheologiju Serta Instituti Archaeologici, Knjiga/vol. 14, Life and Death, Medieval and Early Modern Times, Proceedings of the 5th International Scientific Conference of Mediaeval Archaeology of the Institute of Archaeology Zagreb, 6th and 7th June 2018. Zagreb: 153-166. Zagreb: Institut za arheologiju.

Popa, C. I., Totoianu R., Muntean T. și Radu C. 2016. Un cimitir necunoscut în Cetatea Sebeșului. Cercetări arheologice în colțul sud-vestical incintei orașului. Terra Sebus. Acta Musei Sebesiensis 8: 115-208.

Scott, D. A. 2002. Copper and Bronze in Art: Corrosion, Colorants, Conservation. Los Angeles: Getty Publication.

Smith, C.S., Teach Gnudi, M. 1990. The Pirotechnia of Vannoccio Biringuccio. The Classic Sixteenth Century Treatise on Metals and Metallurgy. New York: Dover Publications Inc.

Snoddy, A. M., Buckley, H. R., Elliott, G. E., Standen, V. G., Arriaza, B., T. și Halcrow S. E. 2018. Macroscopic features of scurvy in human skeletal remains: A literature synthesis and diagnostic guide. American Journal of Physical Anthropology 167, no. 4: 876-895.

Presbyter, T. 1979. De Diversis Artibus (On Divers Arts). Hawthorne, J. G. and Smith, C. S. (ed. and trans.). New York: Dover Publications Inc.

Ţiplic, M. E. 2017. Practica depunerii de monede în cimitirele din Transilvania (secolele XI-XIII). Interpretări și perspective. în Fl. Mărginean, I. Stanciu și D. Băcueț-Crițan (ed.) Orbis Mediaevalis I. Locuirea medievală timpurie din Transilvania și vecinătăți / The Early Medieval Habitation from Transylvania and its Surroundings. Lucrările conferinței naționale Locuirea medievală timpurie din Transilvania și vecinătăți, Lipova (jud. Arad) 2629 octombrie 2016: 301-332. Cluj-Napoca: Editura Mega.

Ubelaker D. H. 1978. Human Skeletal Remains: Excavation, Analysis and Interpretation. Washington D. C.: Taraxacum.

Ubelaker, D. H. 2008. The forensic evaluation of burned skeletal remains: A synthesis. Forensic Science International 183 (1-3):1-5. DOI:19.1016/j.for.sciint.2008.09.019.

Unger, E. 2000. Magyar éremhatározó. II. kötet (1526-1740). Budapest: Ajtósi Dürer Könyvkiadó. 


\title{
SURSE ONLINE
}

***, Evoluția bolilor la români: "De la 1700 încep marile necazuri ale poporului român”, Adevărul, 23 februarie, 2011.

***, Scorbutul sau cât de periculos este deficitul de vitamina C, bioclinica.ro.

CCI Notes 4/ 1, Identifying Archaeological Metal, Canadian Conservation Institute, 2007, https://www.canada.ca/ en/conservation-institute/services/conservation-preservation-publications/canadian-conservation-institute-notes/ identifying-archaeological-metal.html

SILVIU OȚA

MNIR, București

silviuota@yahoo.com

ALEXANDRA COMȘA

IAB, București alexcomsa63@yahoo.com

ZIZI BALTĂ

MNIR, București balta_z_i@yahoo.com

CRISTIANA TĂTARU

MNIR, București

cristiana.tataru@yahoo.com

\author{
ADRIAN ARDET \\ MJERG Caransebeș \\ a.ardet@yahoo.co.uk \\ DIMITRIE NEGREI \\ MJERG, Caransebeș \\ tie_negrei@yahoo.com \\ IULIAN LEONTI \\ MJERG, Caransebeș \\ iulianleonti@gmail.com
}




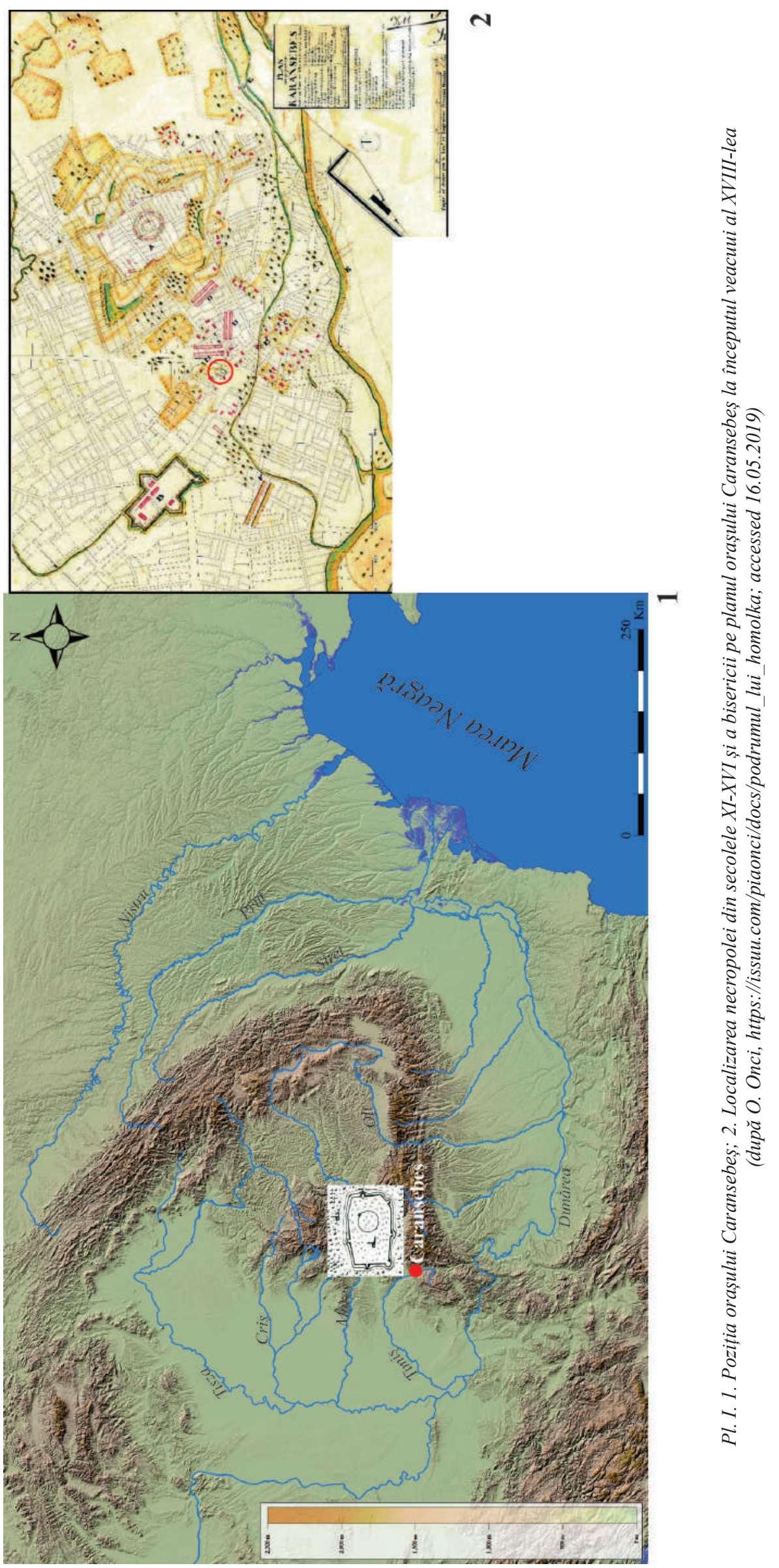




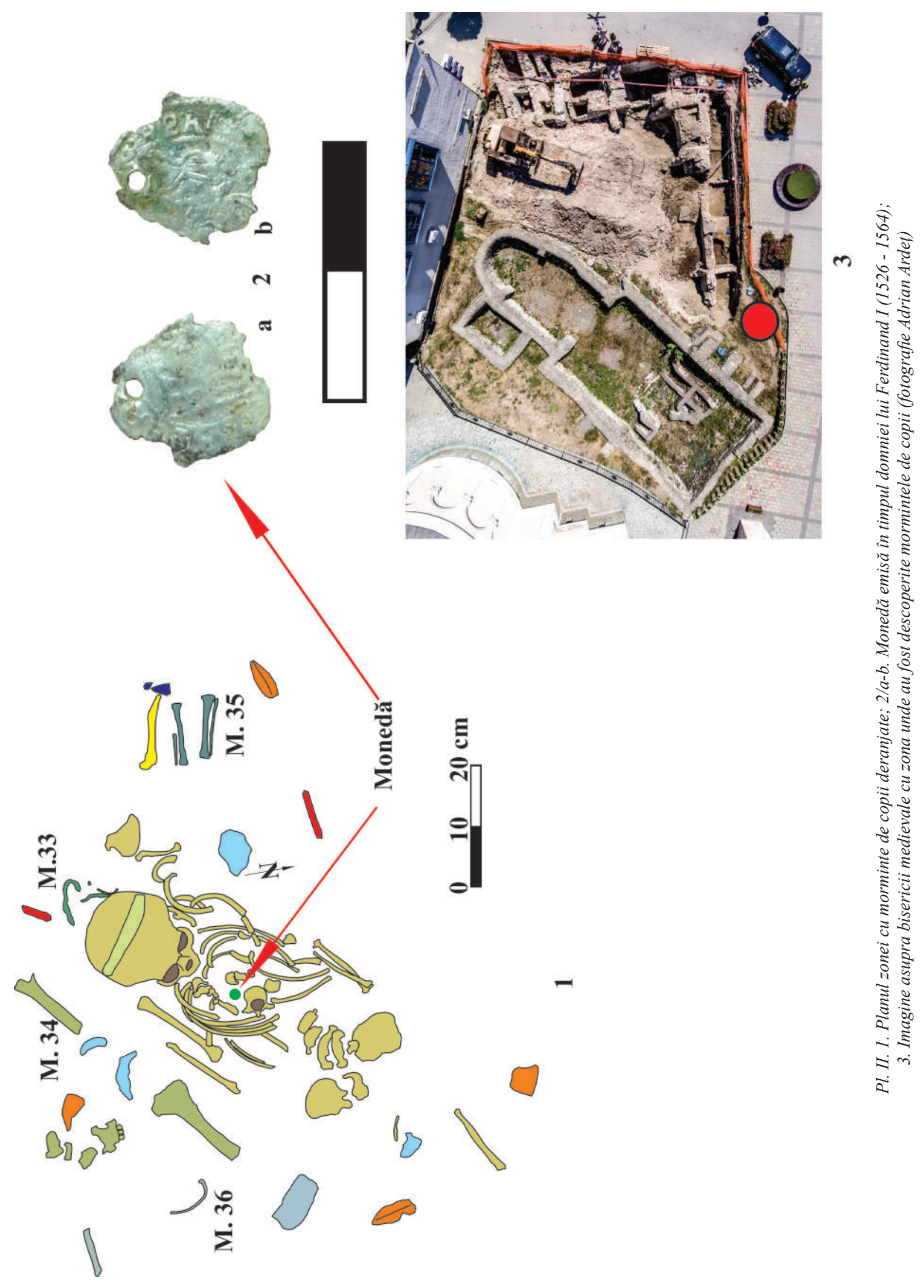




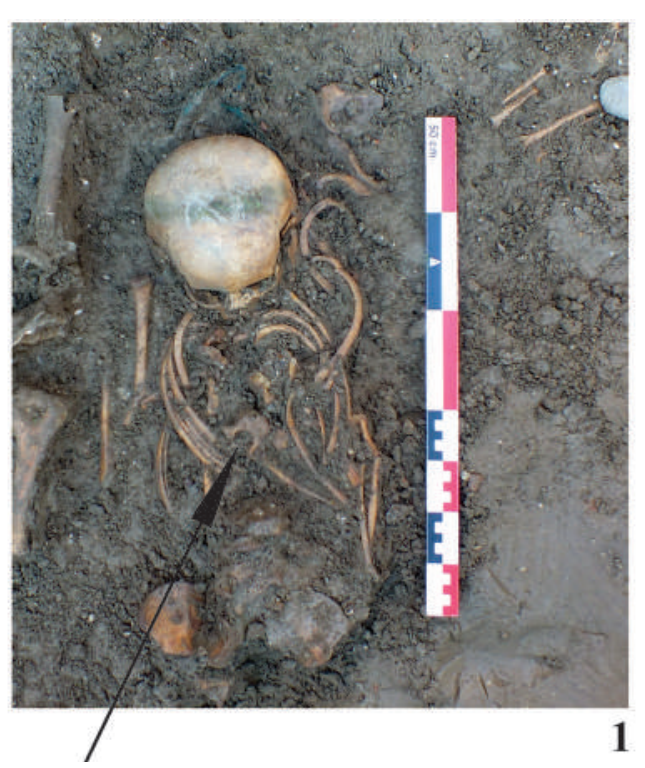

Vertebră din alt mormânt deranjat, probabil M. 34/2017

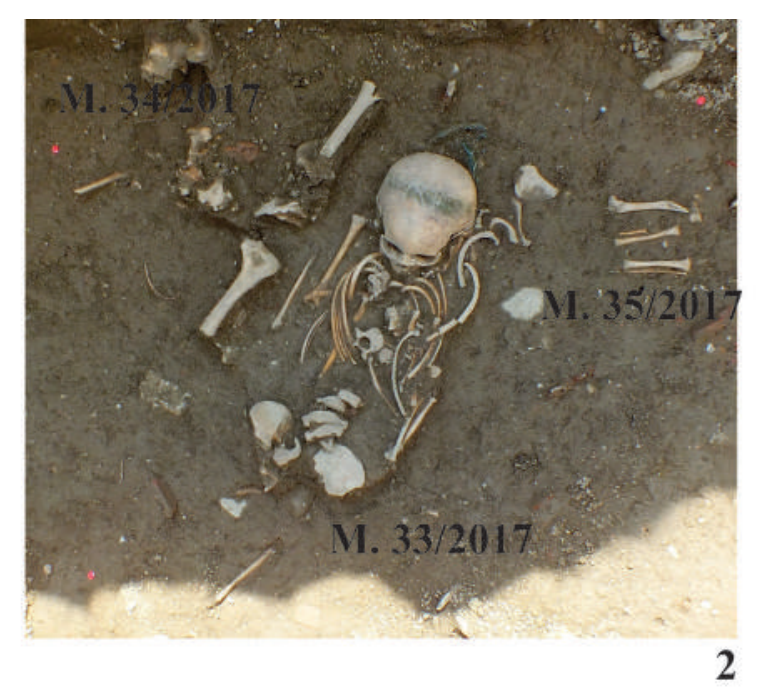

Fragment de țesătură cu fir de argint
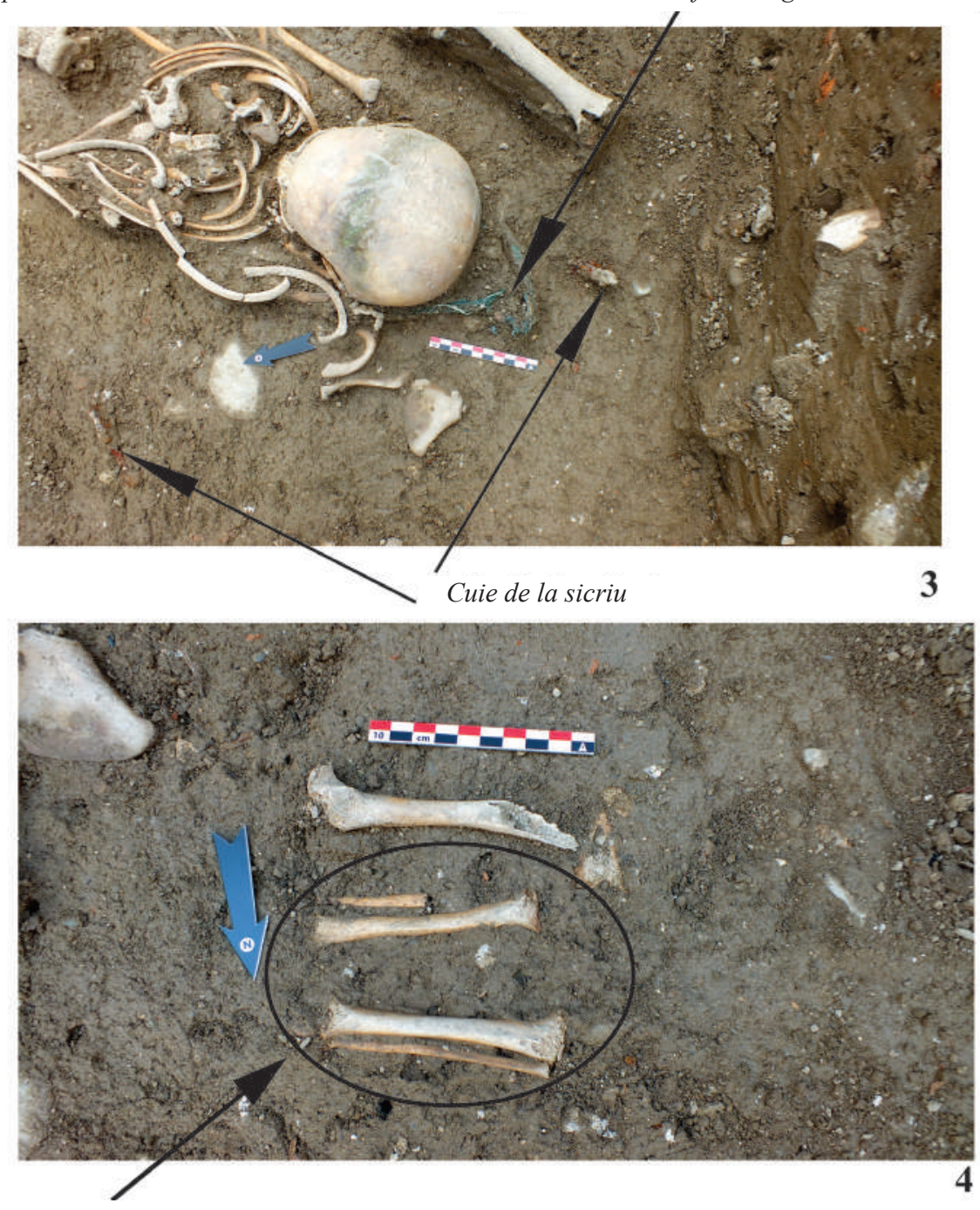

M. 35/2017 și oase disparate din alte complexe funerare.

Pl. III. 1. M. 33/2017. Fotografie de lucru; 2. M. 33, 34, 35/2017; 3. Detaliu din partea superioară a M. 33/2017 4. M. 35/2017 și oase disparate din alte complexe funerare (fotografii Silviu Oța) 
